\title{
Oceanic, Latitudinal, and Sex-Specific Variation in Demography of a Tropical Deepwater Snapper across the Indo-Pacific Region
}

OPEN ACCESS

Edited by:

Lyne Morissette,

M-Expertise Marine, Canada

Reviewed by:

Alexander Tilley,

WorldFish, Malaysia

Valeria Mamouridis,

Independent Researcher, Rome, Italy

*Correspondence:

Ashley J. Williams

ashley.williams@agriculture.gov.au

${ }^{\dagger}$ Present Address:

Simon J. Nicol and Ashley J. Williams, Australian Bureau of Agriculture and Resource Economics and Sciences, Department of Agriculture and Water Resources, Canberra, ACT, Australia

Specialty section:

This article was submitted to Marine Fisheries, Aquaculture and

Living Resources,

a section of the journal

Frontiers in Marine Science

Received: 02 August 2017 Accepted: 14 November 2017 Published: 18 December 2017

Citation:

Williams AJ, Wakefield CB, Newman SJ, Vourey E, Abascal FJ, Halafihi T, Kaltavara J and Nicol SJ (2017) Oceanic, Latitudinal, and Sex-Specific Variation in Demography of a Tropical Deepwater Snapper across the Indo-Pacific Region.

Front. Mar. Sci. 4:382. doi: 10.3389/fmars.2017.00382

\begin{abstract}
Ashley J. Williams ${ }^{1,2 \star \dagger}$, Corey B. Wakefield ${ }^{3}$, Stephen J. Newman ${ }^{3}$, Elodie Vourey ${ }^{1}$, Francisco J. Abascal ${ }^{1,4}$, Tuikolongahau Halafihi ${ }^{5}$, Jeremie Kaltavara ${ }^{6}$ and Simon J. Nicol ${ }^{1,7+}$

${ }^{1}$ Oceanic Fisheries Programme, The Pacific Community, Noumea, New Caledonia, ${ }^{2}$ Centre for Sustainable Tropical Fisheries and Aquaculture, College of Science and Engineering, James Cook University, Townsville, QLD, Australia, ${ }^{3}$ Western Australian Fisheries and Marine Research Laboratories, Department of Primary Industries and Regional Development, Government of Western Australia, North Beach, WA, Australia, ${ }^{4}$ Oceanographic Center of The Canary Islands, Spanish Institute of Oceanography, Santa Cruz de Tenerife, Spain, ${ }^{5}$ Tonga Ministry of Fisheries, Nuku'alofa, Tonga, ${ }^{6}$ Vanuatu Fisheries Department, Ministry of Agriculture, Livestock, Forestry, Fisheries and Biosecurity, Port Vila, Vanuatu, ${ }^{7}$ Faculty of Education, Science, Technology \& Mathematics, Institute for Applied Ecology, University of Canberra, Bruce, ACT, Australia
\end{abstract}

Deepwater tropical fisheries provide an important source of income and protein to Pacific and Indian Ocean coastal communities who are highly dependent on fish for food security. The development of quantitative assessments and management strategies for these deepwater fisheries has been hindered by insufficient biological and fisheries data. We examine the age-specific demography of the pygmy ruby snapper Etelis carbunculus, an important target species in tropical deepwater fisheries, across $90^{\circ}$ of longitude and $20^{\circ}$ of latitude in the Pacific and Indian Oceans. Our results show that growth of E. carbunculus varies significantly between oceans and sexes and across latitudes in both oceans. Estimates of natural and fishing mortality were similar between oceans, but higher for females than males in both oceans. Evidence of greater fishing pressure on females than males is likely due to the larger size-at-age of females compared to males, assuming that selectivity of the fishing gear is related directly to fish size. Sex ratios were significantly female biased in both oceans despite this species being gonochoristic, and maturity schedules were similar between sexes in the Pacific Ocean. This species exhibits a protracted spawning season from mid-spring to autumn (i.e., October to May) in the Pacific Ocean. These results represent the first estimates of age-specific demographic parameters for E. carbunculus, and provide the foundation for the development of the first species-specific assessment models and harvest strategies for the species. Future stock assessment models for $E$. carbunculus should consider sex-specific demographic parameters and spatial variation in demography. Our results reveal substantial differences in biology between $E$. carbunculus and the giant ruby snapper $E$. sp., a cryptic congeneric species, and thus contribute to greater clarity in managing fisheries that are dependent on these two species. Furthermore, the improved information on the life history of E. carbunculus contributes to the broader sustainable management and improved food security for deepwater snapper fisheries in the Indo-Pacific region.

Keywords: Etelis carbunculus, deepwater fisheries, growth, mortality, maturity, data poor fisheries 


\section{INTRODUCTION}

Understanding the biological characteristics of exploited species provides necessary information for developing appropriate assessment models and designing effective fisheries harvest strategies (Hilborn and Walters, 2013). The biological characteristics of deepwater fishes are generally considered to include extended longevity, slow growth rates, late maturity, and low fecundity (Koslow et al., 2000). Thus, deepwater fishes typically have exceptionally low production potential and are considered more vulnerable to overexploitation than shallowwater species (Koslow et al., 2000; Morato et al., 2006; Norse et al., 2012). Increased vulnerability coupled with a global shift in fishing effort toward deeper water (Morato et al., 2006) places greater urgency on advancing our biological understanding, and developing appropriate management measures for the sustainability of deepwater fisheries resources.

Deepwater fisheries occur within all ocean basins and are typically focused upon seamounts, continental and insular slopes, and other deep bathymetric features. In the tropical and subtropical Indo-Pacific region, most deepwater fisheries are small-scale artisanal and subsistence fisheries that have strong cultural and economic value to many Indo-Pacific countries (Dalzell et al., 1996), although there are a small number of deepwater commercial fisheries, mostly in developed countries (Newman et al., 2016). Catches from these fisheries are diverse, with over 200 species from 93 genera reported in the western central Pacific Ocean (Dalzell and Preston, 1992). The most common species harvested are snappers (Lutjanidae), groupers (Epinephelidae) and emperors (Lethrinidae), with the Eteline snappers (Etelis spp. and Pristipomoides spp.) as the principal target species. The status of most deepwater snapper stocks in the Indo-Pacific region is unknown due to insufficient biological and fisheries data (Newman et al., 2017a). Some exceptions include the deepwater snapper fishery for E. coruscans in Tonga, which is considered overfished (Hill et al., 2015), and the fisheries for Pristipomoides multidens in Western Australia (Newman et al., 2017b) and the Northern Territory of Australia (Grubert et al., 2013), which are considered to be fully exploited.

A recent review of the biology of deepwater snappers, groupers and emperors revealed a paucity of information for most species, and highlighted difficulties in taxonomic identification among species, which have likely confounded previous biological studies (Newman et al., 2016). The review emphasized the need for future biological studies of deepwater species to apply consistent methodologies to facilitate direct inter and intra-species comparisons across a species' range. The review also highlighted the need to understand the population structure and dispersal capacity of most tropical deepwater fishes given that recent genetic studies have demonstrated widespread gene flow and high levels of connectivity for several deepwater snapper species across the Indo-Pacific region (Gaither et al., 2011; Andrews et al., 2014; Loeun et al., 2014; Kennington et al., 2017). It is possible, therefore, that many nations are exploiting the same stocks of deepwater snapper, and a shared knowledge of the biology of exploited species, and their population structure would assist in the development of appropriate harvest strategies and management plans. However, even small amounts of gene flow can potentially mask underlying spatial differentiation among populations, which emphasizes the need to understand spatial patterns in biological characteristics to evaluate appropriate scales for management.

Spatial variation in biological characteristics is a common feature of tropical shallow-water reef fish (Gust et al., 2002; Williams et al., 2003; Carter et al., 2014a,b), including species of lutjanids (Newman et al., 1996a; Kritzer, 2002; Cappo et al., 2013), and has been observed at multiple scales ranging from patch reefs on the same reef system $(<1 \mathrm{~km})$ (Pitcher, 1992; Gust et al., 2002) to thousands of kilometers across an ocean basin (Choat et al., 2003; Robertson et al., 2005) as well as between oceans (Trip et al., 2008). Many shallow-water species display a metapopulation structure (Kritzer and Sale, 2006), with spatial separation of adult sub-populations linked to varying degrees by a pelagic larval stage. The metapopulation paradigm may similarly apply to tropical deepwater species which have a strong association with benthic habitats that have a discontinuous and patchy distribution across ocean basins. However, studies of spatial variation in biological characteristics within a stock for tropical deepwater fishes are limited (Wakefield et al., 2013b, 2015). Therefore, it remains unclear whether the patterns of spatial variation in biological characteristics observed for many tropical shallow-water species are also prevalent in stocks of tropical deepwater species.

A recent genetic study revealed that Etelis carbunculus, one of the main target species of deepwater snapper fisheries, comprises two cryptic species, E. carbunculus and E. sp. (Figure S1), with overlapping Indo-Pacific distributions (Andrews et al., 2016). Previously, both species have been reported as a single species (E. carbunculus) in fisheries catch data and in biological studies (Williams et al., 2013). The large difference in the maximum size reached by each of these cryptic species (Williams et al., 2013, 2015; Andrews et al., 2016) indicates that they are likely to have different life histories. Therefore, there is a need to revisit the biology of these two cryptic species to provide accurate estimates of biological parameters to underpin revised assessments and management plans. Here, we examine the agespecific demography of $E$. carbunculus across $90^{\circ}$ of longitude and $20^{\circ}$ of latitude in the western and central Pacific Ocean and the eastern Indian Ocean. Specifically, we examine spatial patterns in sex-specific age and length distributions, growth and mortality, and provide some preliminary estimates of spawning season, and length and age at maturity for the Pacific Ocean. The results contribute to our understanding of spatial patterns in the demography of deepwater tropical species.

\section{MATERIALS AND METHODS Study Area and Sample Collection}

Samples from 366 E. carbunculus were collected from seamounts and the slopes of island reefs and continents in the western and central Pacific Ocean and the eastern Indian Ocean (Table S1; Figure 1). Samples from the Pacific Ocean were collected during scientific surveys and from artisanal landings between October 


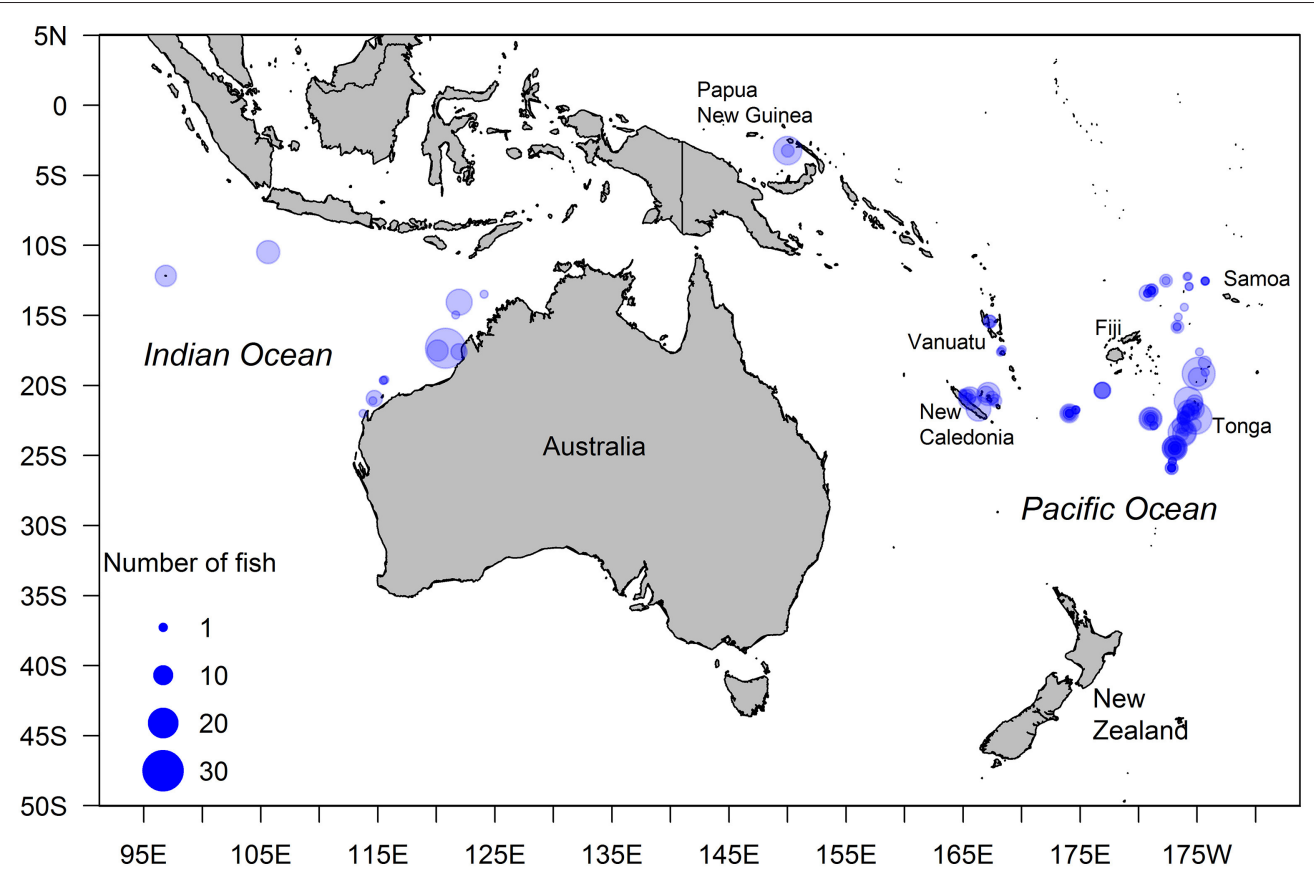

FIGURE 1 | Location of 136 sites where Etelis carbunculus samples were collected (circles) from continental slopes, island reef slopes, and seamounts within Economic Exclusion Zones of the eastern Indian and western central Pacific Island countries and territories.

2012 and April 2014. Fish were captured using vertical multihook droplines from depths ranging between $\sim 100$ and $400 \mathrm{~m}$. Samples from the Indian Ocean were collected during scientific surveys and from commercial (semi-industrial) catches (fish trap and line) between January 1997 and October 2013 in depths ranging between $\sim 100$ and $400 \mathrm{~m}$. The fork length ( $F L$, nearest $\mathrm{cm}$ ) and whole body weight ( $W$, nearest $10 \mathrm{~g}$ ) of each fish was measured and the pair of sagittal otoliths were removed, cleaned, and stored dry in plastic vials or paper envelopes. Most gonads were dissected and stored frozen, then fixed in $10 \%$ buffered formalin on return to the laboratory. Gonads collected from Western Australia and Vanuatu were placed fresh in $10 \%$ buffered formalin.

\section{Age Estimation}

Ages were estimated from thin transverse sections of sagittal otoliths (Figure S2), with the methods used to prepare these sections following those of recent age-based studies on deepwater teleosts (Wakefield et al., 2010, 2013a,b). Briefly, the sagitta of each fish was embedded in epoxy resin and sectioned transversely through the primordium, in a direction perpendicular to the sulcus acusticus, using a low speed saw with a diamond tipped blade. Otolith sections were cut thinly $(0.15-0.20 \mathrm{~mm})$ to improve increment clarity. Sections were rinsed in an acidic solution for $\sim 30 \mathrm{~s}$ ( $2 \%$ hydrochloric acid, see Gauldie et al., 1990) and mounted on glass slides with a cover slip using casting resin. Opaque increments on each otolith section were counted using a compound microscope under reflected light at $\times 50-100$ magnifications. The opaque increments were counted primarily along an axis from the primordium to the otolith margin on the ventral rim of the sulcus acusticus, as this was typically the axis with the most well-defined increments. However, other axes were examined as a reference when opaque increments were unclear on the primary axis. There were no otoliths for which increments were unclear on all axes.

Bomb radiocarbon dating has validated that a single opaque zone is deposited annually in the otoliths of E. sp. (Andrews et al., 2011), and that counts of opaque increments from otolith sections are accurate for determining ages. Although the periodicity in increment formation has not been directly validated for $E$. carbunculus, we presumed that opaque increments in this species also were deposited annually because the two species are closely related and occupy the same habitat. An experienced reader (AJW) counted opaque increments in all otolith sections, and a second experienced reader (CBW) counted opaque increments in a subset of 144 sectioned otoliths. The Index of Average Percent Error (IAPE: Beamish and Fournier, 1981) between increment counts from the two readers was 3.85 , which is within the accepted level of precision for this species (Wakefield et al., 2017a). Therefore, increment counts from the first reader were used as age estimates. For analyses of growth and age at maturity, we estimated a decimal age for each individual using the birth date, the time of year when the opaque increments on the otoliths of the majority of E. carbunculus became delineated (i.e., 1 October), and the number of opaque increments. The birth date of E. carbunculus was considered to be 1 October (the approximate onset of spawning), as determined from the annual trends in gonadosomatic indices (GSI) and prevalence of developmental stages of gonads. 


\section{Gonad Histology}

The total weight of each whole pair of fixed gonads was measured to the nearest $0.1 \mathrm{~g}$. The sex of individuals collected from the Indian Ocean was determined macroscopically. Histology was used to determine the reproductive mode of E. carbunculus and to determine the sex and maturity stage of individuals collected from the Pacific Ocean. Medial transverse sections of gonads of fish from the Pacific Ocean were embedded in paraffin wax, sectioned at $5 \mu \mathrm{m}$, mounted on slides, and stained with Mayer's haematoxylin and eosin. The stage of ovary development was based on the most advanced non-atretic cell type present (West, 1990). Additional features used in histological staging included the structural appearance of lamellae, thickness of the ovarian wall, intra-lamellar stromal tissue, atretic oocytes, brown bodies, and postovulatory follicles, all of which are indicators of prior spawning (Sadovy and Shapiro, 1987). Ovaries and testes were classified into developmental stages adapted from Ferreira (1995) and Adams (2003). Females were classified into five stages: immature (I), mature resting (II), developing (III), ripe (IV), and hydrated (V). Males were classified into four stages: immature (I), mature resting (II), ripe (III) and spent (IV).

\section{Length and Age Distributions}

Length and age frequency distributions were constructed for females and males in the Pacific and Indian Oceans. We used Kolmogorov-Smirnov (K-S) tests to compare length and age frequency distributions between sexes within the Pacific and Indian Ocean, and between oceans.

\section{Growth}

The relationship between $F L$ and $W$ was estimated for E. carbunculus from the Pacific Ocean only, because no weight data were collected from the Indian Ocean. We modeled the $F L-W$ relationship using a power function of the form $W=a$ $\times F L^{b}$, where $a$ is the coefficient of the power function, and $b$ is the exponent. Generalized linear mixed-effects models (GLMM) were used to examine the effects of sex and latitude on the FL$W$ relationship. Length and weight data were log-transformed to satisfy the assumption of linearity. Fishing set (location and date of sampling) was modeled as a random effects term in the GLMM models because multiple individual fish were often sampled at the same time from a single location, and therefore not all samples were independent. We modeled $\log (F L)$ and sex as fixed factors and latitude as a covariate. We evaluated support for the inclusion of terms for sex and latitude in the $F L-W$ relationship using the Akaike's Information Criteria for small sample sizes $\left(\mathrm{AIC}_{\mathrm{c}}\right.$ : Burnham and Anderson, 2002). Models with an $\mathrm{AIC}_{\mathrm{c}}$ value within two of that calculated for the best approximating model (lowest $\mathrm{AIC}_{\mathrm{c}}$ ) were considered to describe the data equally well (Burnham and Anderson, 2002). The Akaike weight, $w_{i}$, of each model $i$ was calculated to quantify the plausibility of each model, given the data and the set of $n$ models using:

$$
w_{i}=\frac{\exp \left(-0.5 \Delta_{i}\right)}{\sum_{k=1}^{n} \exp \left(-0.5 \Delta_{i}\right)}
$$

where $\Delta_{i}=\mathrm{AIC}_{\mathrm{c}, \min }-\mathrm{AIC}_{\mathrm{c}, i}$. The Akaike weight is considered as the weight of evidence in favor of model $i$ being the actual best model of the available set of all models (Burnham and Anderson, 2002).

We fitted the von Bertalanffy growth function (VBGF) to E. carbunculus length-at-age data using non-linear least squares to explore trends in growth. The form of the VBGF was:

$$
L_{i}=L_{\infty i}\left(1-\exp \left(-k_{i}\left(t_{i}-t_{0 i}\right)\right)\right)
$$

where $L_{i}$ and $t_{i}$ are the mean fork length (cm) and age (years) of the $i$ th fish, respectively, $L_{\infty i}$ is the mean asymptotic length, $k_{i}$ is a relative growth rate parameter $\left(\right.$ year $^{-1}$ ), and $t_{0 i}$ is the age at which fish have a theoretical length of zero. We constrained the parameter $t_{0 i}$ to zero given the lack of smaller fish in the samples.

We evaluated the effects of sex, ocean, and latitude on the VBGF for E. carbunculus using the extended VBGF described by Kimura (2008) whereby sex, ocean, and latitude were added as covariates $(\beta)$ on the VBGF parameters $L_{\infty}$ and $k$, such that the general form of the extended VBGF with all covariates was:

$$
\left(\begin{array}{c}
L_{\infty i} \\
K_{i}
\end{array}\right)=\left(\begin{array}{c}
\beta_{0 L}+x_{i 1} \beta_{1 L}+x_{i 2} \beta_{2 L}+x_{i 3} \beta_{3 L} \\
\beta_{0 K}+x_{i 1} \beta_{1 K}+x_{i 2} \beta_{2 K}+x_{i 3} \beta_{3 K}
\end{array}\right)
$$

where $x_{i 1}$ and $x_{i 2}$ are dummy variables for sex (female or male) and ocean (Pacific or Indian), set to either 0 or 1 , and $x_{i 3}$ is an explanatory variable for latitude, for the $i$ th fish. No covariates were applied to $t_{0}$ because it was fixed at zero, and the effects of the covariates on $L_{\infty}$ and $k$ were expected to be greater than on $t_{0}$. We evaluated support for the inclusion of covariates for ocean, sex, and latitude on VBGF parameters using $\mathrm{AIC}_{\mathrm{c}}$. This analysis revealed substantial support for the inclusion of all three covariates, indicating that growth of E. carbunculus varied by sex, ocean, and latitude. Therefore, given that there were only two levels of sex and ocean, separate growth models for females and males in the Pacific and Indian Ocean were used to explore latitudinal variation in growth.

Two approaches were used to evaluate latitudinal variation in growth. First, we explored latitudinal variation in length-at-age using GLMMs to model the effects of latitude on the residual length-at-age data from the growth models fitted to female and male length-at-age for each ocean. The relationship between the residuals and latitude was then evaluated by modeling latitude as a linear and non-linear (cubic spline with 2 or 3 degrees of freedom) variable. Secondly, we used the extended VBGF to explore the shape of the relationship between VBGF parameters and latitude by modeling $L_{\infty}$ and $k$ as linear and non-linear functions of latitude for male and female growth models in each ocean. $\mathrm{AIC}_{\mathrm{c}}$ was used to determine which models were best supported by the data.

\section{Mortality}

We used the GLMM estimator proposed by Millar (2015) to estimate instantaneous rates of total mortality $(Z)$ for E. carbunculus. This method outperforms the Chapman-Robson and weighted-regression estimators, especially in cases where there is variability in recruitment to the fishery, variability in 
annual survival, autocorrelated recruitment, and aging error (Millar, 2015). We fitted random-intercept Poisson loglinear models using GLMMs separately to age frequency data for females and males from the Pacific and Indian Oceans, with the frequency of fish in each age class as the response variable, age as a fixed factor, and a random intercept. Age data were pooled across oceans and sexes to determine a common modal age (age at full selectivity to the fishery), and all models were fitted to data for age classes equal to or greater than the modal age (i.e., assuming asymptotic selectivity). The estimate of $Z$ was the negative of the maximum likelihood estimator of the slope coefficient from each model.

We estimated the natural mortality rate $(M)$ for female and male E. carbunculus from the Pacific and Indian Oceans by fitting the linear equation $\log _{e}(M)=1.44-1.01 \times \log _{e}\left(t_{\max }\right)$, where $t_{\max }$ is the maximum age observed (Hoenig, 1983). Estimates of fishing mortality $(F)$ were calculated as the difference between $Z$ and $M$, which was then used to estimate the exploitation ratio $(E=F / Z)$.

\section{Sex Ratio, Spawning Period, and Maturity}

Overall sex ratios in the Pacific and Indian Oceans were compared with an expected ratio of $1: 1$ by $\chi^{2}$ goodness-of-fit tests using all samples (immature and mature). Sex ratios were then plotted against $F L$ to examine trends in sex ratio with size for both oceans.

There were insufficient data from the Indian Ocean to examine reproductive seasonality or maturity of E. carbunculus. Furthermore, there were insufficient data to examine latitudinal variation in reproductive seasonality or maturity within the Pacific Ocean. Therefore, we examined these characteristics for data pooled across the Pacific Ocean. A gonadosomatic index (GSI: gonad weight/ $W * 100$ ) was calculated for each female fish. The relationship between $F L$ and $W$ was used to estimate $W$ for individual fish where weight data were unavailable. The monthly trends in GSI and the proportion of females in spawning condition (stages IV and V) were examined to determine the annual spawning period for E. carbunculus in each ocean. A linear regression was fitted to $W$ and gonad weight for mature females collected during spawning months to examine whether relative reproductive output increases with body size. Data were $\log$ transformed to meet the assumption of homoscedasticity.

We used generalized linear models to estimate the length and age at maturity of female and male E. carbunculus in the Pacific Ocean. Maturity state was treated as a binomial response variable with logit link function and modeled as a function of either age or FL.

All statistical analyses were conducted in the statistical software environment $\mathrm{R}$ version 3.3.1 ( $\mathrm{R}$ Core Team, 2016). We used the function $n l s$ in the package stats for non-linear modeling of the extended VBGF, and the glmer function in the package lme4 for all GLMMs.

\section{RESULTS}

\section{Length and Age Distributions}

We detected statistically significant differences in length $(D=$ $0.57, p=0.002)$ and age frequency distributions $(D=0.56, p$
$<0.001)$ between the Pacific and Indian Ocean, with a greater proportion of larger fish $(>40 \mathrm{~cm} \mathrm{FL)} \mathrm{in} \mathrm{the} \mathrm{Pacific} \mathrm{Ocean} \mathrm{(mean}$ $=40.0 \mathrm{~cm} F L, S D=8.0$ ) than in the Indian Ocean (mean $=$ $34.8 \mathrm{~cm} \mathrm{FL}, S D=5.2$ ) (Figure 2). The range of ages was similar between the Pacific (mean $=13.0$ years, $S D=5.0$ ) and Indian Oceans (mean $=11.1$ years, $S D=6.3$ ), but there was a lower proportion of young fish ( $<6$ years) and a greater proportion of old fish ( $>13$ years) in the Pacific Ocean than in the Indian Ocean (Figure 2). We detected statistically significant differences in length $(D=0.55, p=0.005)$ and age frequency distributions $(D=0.44, p=0.02)$ between females and males in the Pacific Ocean, but no significant differences in length $(D=0.36, p=$ $0.46)$ and age frequency distributions $(D=0.3, p=0.33)$ between females and males in the Indian Ocean. The low sample sizes in the Indian Ocean may have contributed to the inability to detect significant differences between males and females.

\section{Growth}

We found no effect of sex or latitude on the $F L-W$ relationship of E. carbunculus as indicated by a larger $\mathrm{AIC}_{\mathrm{c}}$ and lower weight of evidence for models including terms for sex and latitude (Table 1). Therefore, we pooled data across sexes and locations to estimate the $F L-W$ relationship for the Pacific Ocean (Figure 3). The estimated parameters and 95\% confidence intervals of the $F L-W$ relationship $\left(a=(1.10 \pm 0.26) \times 10^{-5}\right.$, $b=3.13 \pm 0.07)$ indicate that $E$. carbunculus exhibit a positively allometric growth pattern $(b>3)$, in which their weight increases disproportionately to length.

Fitting the VBGF to E. carbunculus length-at-age data revealed that growth parameters were affected significantly by ocean, sex, and latitude (Table 2). The estimated mean asymptotic length $\left(L_{\infty}\right)$ was much greater, and the estimate of $k$ much lower for females and males in the Pacific Ocean than in the Indian Ocean (Table 3; Figure 4). The estimated $k$ was similar for both females and males in the Pacific Ocean, but the estimated $L_{\infty}$ was more than $6 \mathrm{~cm}$ larger (13\%) for females than for males (Table 3; Figure 4). The estimated $L_{\infty}$ was similar between females and males in the Indian Ocean, but the estimated $k$ was higher for females than males (Table 3). For both sexes, E. carbunculus attained a larger $L_{\infty}$ in the Pacific than in the Indian Ocean.

GLMMs revealed that the residual length-at-age from the VBGF models for females and males varied significantly with latitude in the Pacific and Indian Oceans (Table 4). The relationship between residual length-at-age and latitude was described best by a cubic spline with 3 degrees of freedom for females and males in both the Pacific and Indian Oceans, as indicated by the lowest $\mathrm{AIC}_{\mathrm{c}}$ values for these models (Table 4). There was a strong relationship between the residuals and latitude for both females and males (Figures 5A,D). In the Pacific Ocean, residual length-at-age for females and males was predicted to be consistently greater at higher latitudes $\left(>22^{\circ} \mathrm{S}\right)$ than at lower latitudes (Figure 5A). There were no data available from areas south of $21^{\circ} \mathrm{S}$ in the Indian Ocean to evaluate if this trend occurred in both oceans. There was a tendency for residual length-at-age for females and males to be slightly greater at the lowest latitudes $\left(<12^{\circ} \mathrm{S}\right)$ than at mid-latitudes $\left(12-18^{\circ} \mathrm{S}\right)$ in both oceans. 


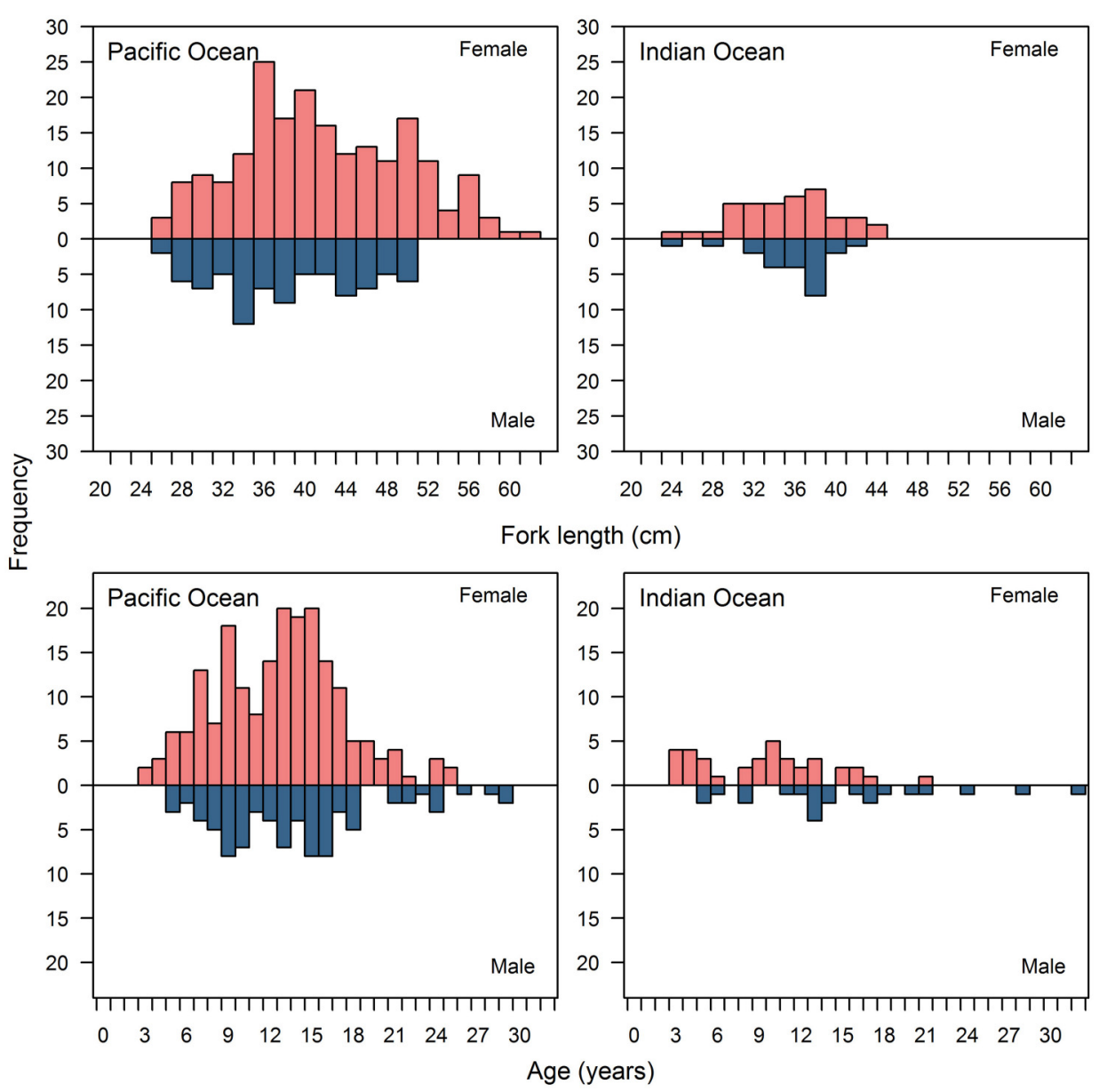

FIGURE 2 | Length and age frequency distributions for female and male Etelis carbunculus from the Pacific and Indian Oceans.

TABLE 1 | Summary of generalized linear mixed effects models (GLMM) used to examine the effects of sex and latitude (lat) on the relationship between fork length $(F L)$ and weight $(W)$ for Etelis carbunculus from the Pacific Ocean.

\begin{tabular}{lccccc}
\hline Model & Df Deviance & $\mathbf{A I C}_{\mathbf{c}}$ & $\boldsymbol{\Delta A I C}_{\mathbf{c}}$ & $\boldsymbol{w}$ \\
\hline $\log (W)=\log (F L)+\beta_{\text {set }}+\varepsilon$ & 4 & -453.2 & -432.7 & 0 & 0.73 \\
$\log (W)=\log (F L)+\alpha_{\text {lat }}+\beta_{\text {set }}+\varepsilon$ & 5 & -463.9 & -430.6 & 2.1 & 0.26 \\
$\log (W)=\log (F L)+$ Sex $+\beta_{\text {set }}+\varepsilon$ & 5 & -453.2 & -424.0 & 8.7 & 0.01 \\
$\log (W)=\log (F L)+$ Sex $+\alpha_{\text {lat }}+\beta_{\text {set }}+\varepsilon$ & 6 & -464.2 & -422.2 & 10.4 & $<0.01$ \\
\hline
\end{tabular}

$\beta_{\text {set }}$ is the random effect of fishing set, and $\varepsilon$ is the error term. Df is the degrees of freedom, $A / C_{C}$ is the small-sample bias-corrected form of Akaike's information criterion, $\triangle A I C_{C}$ is the Akaike difference, and $w$ is the Akaike weight.

The shape of the relationship between the VBGF parameters $L_{\infty}$ and $k$, and latitude was significantly non-linear for female and male growth models in the Pacific and Indian Oceans (Table 5; Figures 5B,C,E,F). A growth model with non-linear variation in $k$ and $L_{\infty}$ was best supported by the data in all cases, although there was equivalent support $\left(\Delta \mathrm{AIC}_{\mathrm{c}}\right.$ $<2$ ) for models with linear variation in $k$ for males in both oceans (Table 5). In the Pacific Ocean, growth models predicted a significantly larger $L_{\infty}$ and smaller $k$ at higher latitudes $\left(>20^{\circ} \mathrm{S}\right)$ than at lower latitudes for both females and males (Figures 5B,C), similar to the trends in fork length residuals (Figure 5A ). Latitudinal trends in $L_{\infty}$ and $k$ were less pronounced in the Indian Ocean (Figures 5E,F), but there was a tendency for a larger $L_{\infty}$ and smaller $k$ at the lowest $\left(<14^{\circ} \mathrm{S}\right)$ and highest $\left(>18^{\circ} \mathrm{S}\right)$ latitudes than at intermediate latitudes.

\section{Mortality}

The estimated instantaneous rate of total mortality $(Z)$ for E. carbunculus was similar between the Pacific and Indian Oceans for females and males (Table 6). Estimates of $Z$ were greater for females than males in both oceans, although the uncertainty in estimates was greater in the Indian Ocean due to lower sample sizes. Estimates of natural mortality $(M)$ were also greater for females than males in the Pacific and Indian Oceans, with males reaching an older age in both oceans. However, the differences in $Z$ between females and males were not due entirely to differences in $M$, with estimates of $F$ more than two-fold greater for females 


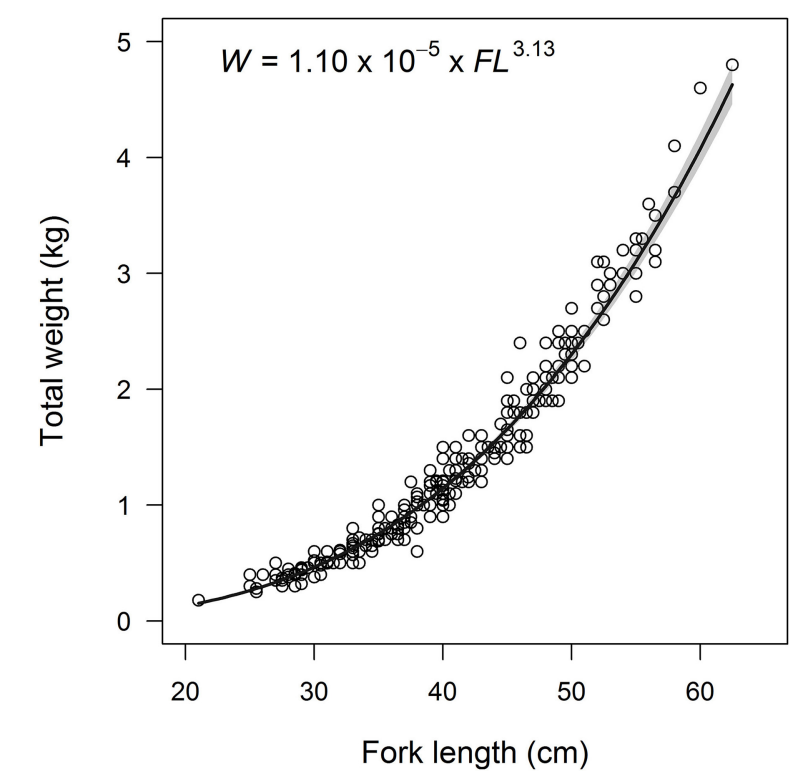

FIGURE 3 | Weight-at-length data and estimated power curve for Etelis carbunculus from the Pacific Ocean. Shaded area indicates 95\% confidence intervals.

TABLE 2 | Comparison of von Bertalanffy growth models fitted to E. carbunculus length-at-age data with covariates for ocean, sex, and latitude.

\begin{tabular}{lccccc}
\hline $\begin{array}{l}\text { Covariate(s) used in } \\
\text { model }\end{array}$ & $\begin{array}{c}\text { No. of } \\
\text { parameters }\end{array}$ & RSS & $\mathbf{A I C}_{\mathbf{c}}$ & $\boldsymbol{\Delta A I C}_{\mathbf{c}}$ & $\boldsymbol{w}$ \\
\hline Ocean, sex, and latitude & 12 & 8281.3 & 2048.8 & 0 & 1.00 \\
Sex and latitude & 9 & 8689.1 & 2060.8 & 11.9 & 0 \\
Ocean and sex & 9 & 9074.8 & 2075.4 & 26.5 & 0 \\
Ocean and latitude & 9 & 9572.6 & 2093.3 & 44.5 & 0 \\
Ocean & 6 & 10182.2 & 2109.9 & 61.1 & 0 \\
Sex & 6 & 10186.0 & 2110.0 & 61.2 & 0 \\
Latitude & 6 & 10257.8 & 2112.4 & 63.6 & 0 \\
No covariates & 3 & 11652.3 & 2151.1 & 102.3 & 0
\end{tabular}

RSS is the residual sum of squares for each model, $A / C_{C}$ is the small-sample biascorrected form of Akaike's information criterion, $\triangle A / C_{C}$ is the Akaike difference, and $w$ is the Akaike weight.

than for males in both oceans, resulting in higher exploitation ratios $(E)$ for females in both oceans (Table 6).

\section{Sex Ratio, Spawning Period, and Maturity}

Gonad characteristics of E. carbunculus were consistent with gonochorism, with no evidence of transitional reproductive tissue, no remnant bisexual characteristics, and only ever testicular or ovarian tissue present in one gonad (Figure S3). Sampled populations of $E$. carbunculus were significantly female biased in both the Pacific $\left(2.4: 1 ; \chi^{2}=47.05 ; p<0.001\right)$, and Indian $\left(1.7: 1 ; \chi^{2}=4.13 ; p=0.04\right)$ Oceans. Furthermore, sex ratios were at unity or female biased in all length classes except 38 $\mathrm{cm} F L$ in the Indian Ocean (Figure 6). The sex ratio tended to be more female biased at greater lengths, particularly in the Pacific Ocean. There were no males in any length classes $>50 \mathrm{~cm} \mathrm{FL}$.
TABLE 3 | Parameter estimates ( \pm s.e.) from von Bertalanffy growth models fitted to male and female Etelis carbunculus from the Indian and Pacific Oceans.

\begin{tabular}{llcc}
\hline Ocean & Sex & $\boldsymbol{L}_{\infty}$ & $\boldsymbol{k}$ \\
\hline Pacific & Female & $51.38(1.39)$ & $0.14(0.01)$ \\
& Male & $45.37(1.48)$ & $0.15(0.02)$ \\
\hline \multirow{2}{*}{ Indian } & Female & $38.06(0.85)$ & $0.38(0.04)$ \\
& Male & $37.79(0.87)$ & $0.27(0.04)$
\end{tabular}

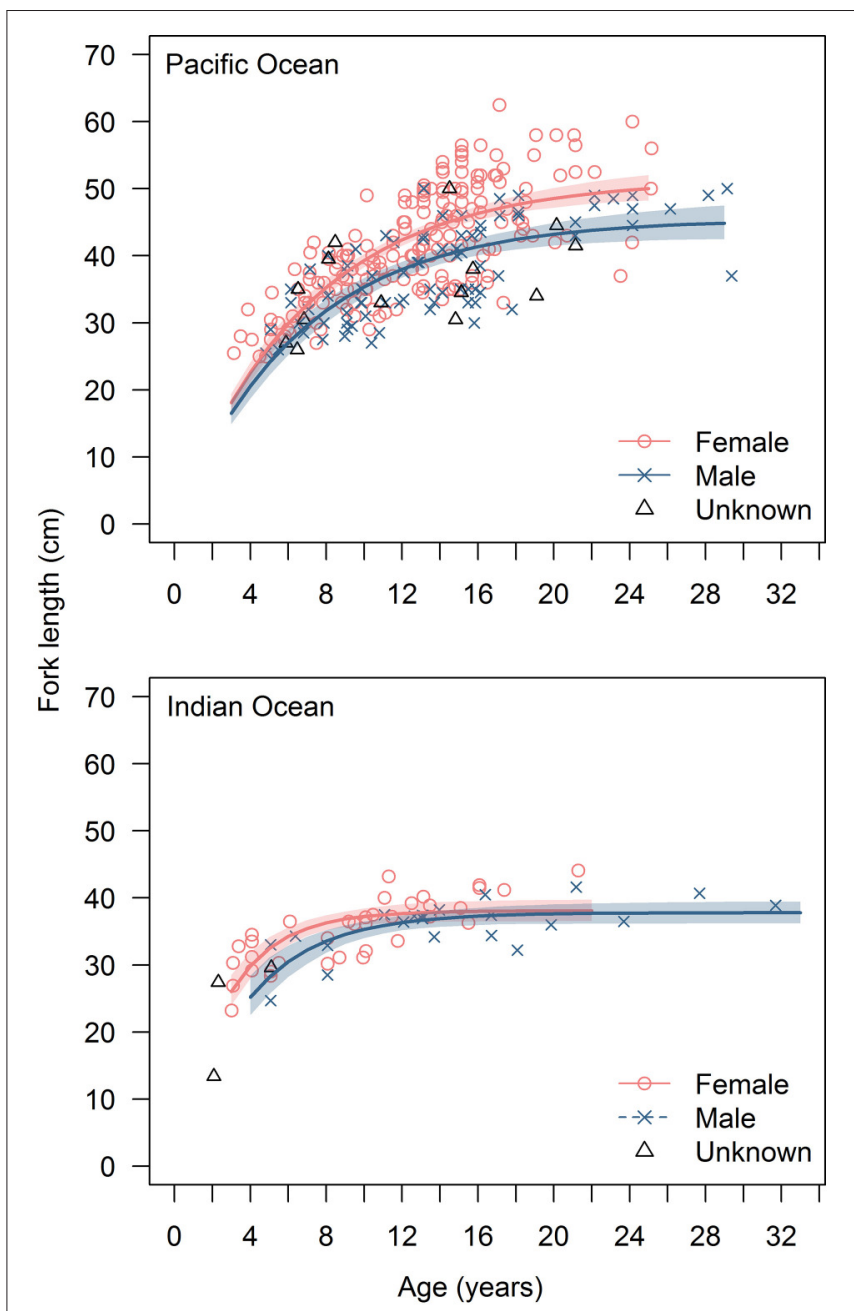

FIGURE 4 | Length-at-age data and fitted von Bertalanffy growth curves for female and male Etelis carbunculus from the Pacific and Indian Oceans. Shaded areas indicate 95\% confidence intervals.

The weight of mature female gonads in the Pacific Ocean increased significantly with body weight $(F=209.74, p<0.001)$, with the predicted gonad weight of a $3 \mathrm{~kg}$ female more than four times greater than for a $1 \mathrm{~kg}$ female (Figure 7). Mean monthly GSI values for mature female E. carbunculus in the Pacific Ocean were highest in the months from January to May, but were also elevated ( $>2$ ) in November (Figure 8). Developing ovaries (stage III) were observed in all months except June, while ripe and hydrated ovaries (stages IV \& V) were observed in most of the months between October and May (Figure 8). The low sample 
TABLE 4 | Parameter estimates from generalized linear mixed-effects models examining the effects of latitude (lat) on residual fork length $(R)$ from von Bertalanffy growth models for male and female Etelis carbunculus in the Pacific and Indian Oceans.

\begin{tabular}{|c|c|c|c|c|c|c|}
\hline Ocean & Sex & Model & Deviance & $\mathrm{AlC}_{\mathrm{c}}$ & $\Delta \mathrm{AlC}_{\mathrm{c}}$ & $w$ \\
\hline \multirow[t]{8}{*}{ Pacific } & Female & $R=s($ lat,$d f=3)+\beta_{\text {set }}+\varepsilon$ & 1163.1 & 1164.1 & 0 & 0.82 \\
\hline & & $R=s(l a t, d f=2)+\beta_{\text {set }}+\varepsilon$ & 1165.3 & 1167.1 & 3.1 & 0.18 \\
\hline & & $R=$ lat $+\beta_{\text {set }}+\varepsilon$ & 1182.9 & 1193.2 & 29.1 & 0 \\
\hline & & $R=\beta_{\text {set }}+\varepsilon$ & 1196.7 & 1202.2 & 38.1 & 0 \\
\hline & Male & $R=s($ lat,$d f=3)+\beta_{\text {set }}+\varepsilon$ & 454.7 & 455.0 & 0 & 0.88 \\
\hline & & $R=s(l a t, d f=2)+\beta_{\text {set }}+\varepsilon$ & 457.8 & 459.1 & 4.0 & 0.12 \\
\hline & & $R=\beta_{\text {set }}+\varepsilon$ & 474.7 & 484.0 & 29.0 & 0 \\
\hline & & $R=$ lat $+\beta_{\text {set }}+\varepsilon$ & 478.6 & 484.4 & 29.3 & 0 \\
\hline \multirow[t]{8}{*}{ Indian } & Female & $R=s($ lat,$d f=3)+\beta_{\text {set }}+\varepsilon$ & 185.8 & 183.8 & 0 & 0.79 \\
\hline & & $R=s($ lat,$d f=2)+\beta_{\text {set }}+\varepsilon$ & 186.5 & 186.7 & 2.9 & 0.19 \\
\hline & & $R=\beta_{\text {set }}+\varepsilon$ & 187.0 & 191.8 & 8.0 & 0.02 \\
\hline & & $R=$ lat $+\beta_{\text {set }}+\varepsilon$ & 187.0 & 194.7 & 10.9 & 0 \\
\hline & Male & $R=s($ lat,$d f=3)+\beta_{\text {set }}+\varepsilon$ & 101.3 & 106.1 & 0 & 0.80 \\
\hline & & $R=s($ lat,$d f=2)+\beta_{\text {set }}+\varepsilon$ & 105.5 & 109.3 & 3.2 & 0.16 \\
\hline & & $R=\beta_{\text {set }}+\varepsilon$ & 105.6 & 112.7 & 6.7 & 0.03 \\
\hline & & $R=$ lat $+\beta_{\text {set }}+\varepsilon$ & 106.2 & 115.8 & 9.7 & 0.01 \\
\hline
\end{tabular}

$\beta_{\text {set }}$ is the random effect of fishing set, and $\varepsilon$ is the error term. $A l C_{C}$ is the small-sample bias-corrected form of Akaike's information criterion, $\triangle A / C_{C}$ is the Akaike difference, and $w$ is the Akaike weight.

size in some months is the likely reason that ripe and hydrated ovaries were not observed in some months between October and May. Nevertheless, the observed trends in monthly GSI and frequency of mature ovarian stages suggest either multiple spawning seasons or, more likely, a protracted spawning season for E. carbunculus between October and May in the Pacific Ocean.

The size and age at maturity was similar for female and male E. carbunculus in the Pacific Ocean. The smallest and youngest mature female observed was $25 \mathrm{~cm} \mathrm{FL}$ and 3 years of age, and the largest and oldest immature female was $33.5 \mathrm{~cm} \mathrm{FL}$ and 6 years of age (Figure 9). The smallest and youngest mature male observed was $27 \mathrm{~cm} \mathrm{FL}$ and 6 years of age, and the largest and oldest immature male was $34.5 \mathrm{~cm} \mathrm{FL}$ and 9 years of age (Figure 9). The estimated size and age at which $50 \%$ of females reached maturity was $27.5 \mathrm{~cm} \mathrm{FL}$ and 4.8 years of age. For males, $50 \%$ were estimated to be mature at $27.6 \mathrm{~cm} \mathrm{FL}$ and 5.1 years of age.

\section{DISCUSSION}

The lack of age-based biological studies for tropical deepwater fishes has limited the ability to develop effective fisheries assessment models and appropriate management and harvest strategies (Newman et al., 2015, 2016, 2017a). Here, we have provided the first estimates of age-specific demographic parameters for E. carbunculus since the species was discovered to comprise two cryptic species (E. carbunculus and E. sp.) (Wakefield et al., 2014; Andrews et al., 2016). Prior to the description of the distinction between these two species, the only information on the biology of E. carbunculus that was available was from Hawaii, where only E. carbunculus occurs. Studies of E. carbunculus from other locations throughout the Indo-Pacific region are most likely biased due to unknown proportions of the sympatric E. sp. and E. carbunculus in the samples collected. We extend the knowledge of the biology of E. carbunculus further by providing comparisons of demographic parameters between oceans and sexes, and with comparisons of growth across $20^{\circ}$ of latitude. Our results show that growth of E. carbunculus varies significantly between oceans and sexes and across latitudes in both oceans. Estimates of natural and fishing mortality were similar between oceans, but higher for females than males in both oceans. Sex ratios were significantly female biased in both oceans, despite this species being gonochoristic, and maturity schedules were similar between sexes in the Pacific Ocean. These results provide the foundation for the development of the first speciesspecific assessment models for E. carbunculus and highlight the need to consider sex-specific demographic parameters and spatial variation in demography in future stock assessment models.

Spatial variation in the demography of fishes may result from variation in environmental factors, genetics, or a combination of both (Conover et al., 2006). Separating the effects of phenotypic and genotypic variation is difficult, and transplant experiments are usually employed to control environmental variables so as to reveal the environmental and genetic components of phenotypic variation (Conover et al., 2006). Such experiments are possible for small shallow-water sedentary species, but impractical for larger deepwater species such as E. carbunculus. Recent genetic studies have revealed widespread gene flow and high levels of connectivity for several deepwater snapper species across the Indo-Pacific region, including for E. carbunculus, E. coruscans (Andrews et al., 2014), E. sp (Loeun et al., 2014), Pristipomoides filamentosus (Gaither et al., 2011) and P. zonatus (Kennington et al., 2017). These results suggest that environmental factors are likely to be important drivers of the observed spatial variation in the demography of E. carbunculus. For example, the nutrientpoor Leeuwin current which dominates the oceanography along the west coast of Australia is thought to influence the demography and productivity of fishes (Molony et al., 2011), and may explain the observed differences in demography of E. carbunculus between the two oceans. Widespread gene flow also indicates that the metapopulation paradigm is applicable to populations of E. carbunculus, and most likely other deepwater snapper species, whereby a large network of populations with similar dynamics are connected via larval dispersal (Kritzer and Sale, 2006). It will be important, therefore, to recognize the appropriate spatial scales and the metapopulation structure of deepwater snapper species in the development of stock assessments and harvest strategies.

Previous estimates of growth parameters for E. carbunculus from Hawaii (Smith and Kostlan, 1991) differ substantially from those estimated in this study. However, it is not appropriate to make direct comparisons between these studies due to the significant bias in the numerical integration techniques used by Smith and Kostlan (1991) to determine the age of fish (Newman et al., 2016). Our estimates of growth are based on aging methods that have been validated with bomb radiocarbon 

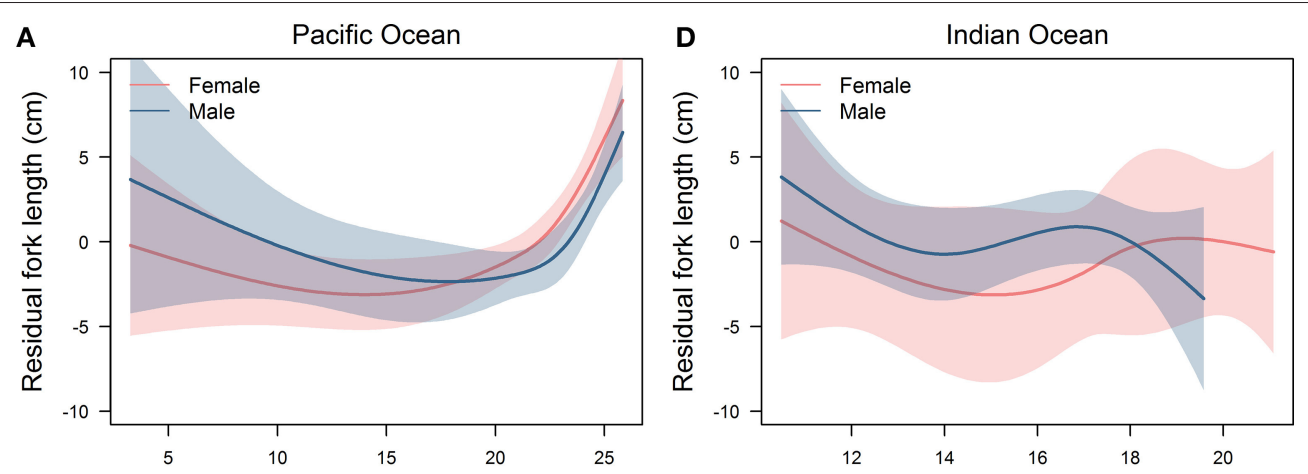

B

E
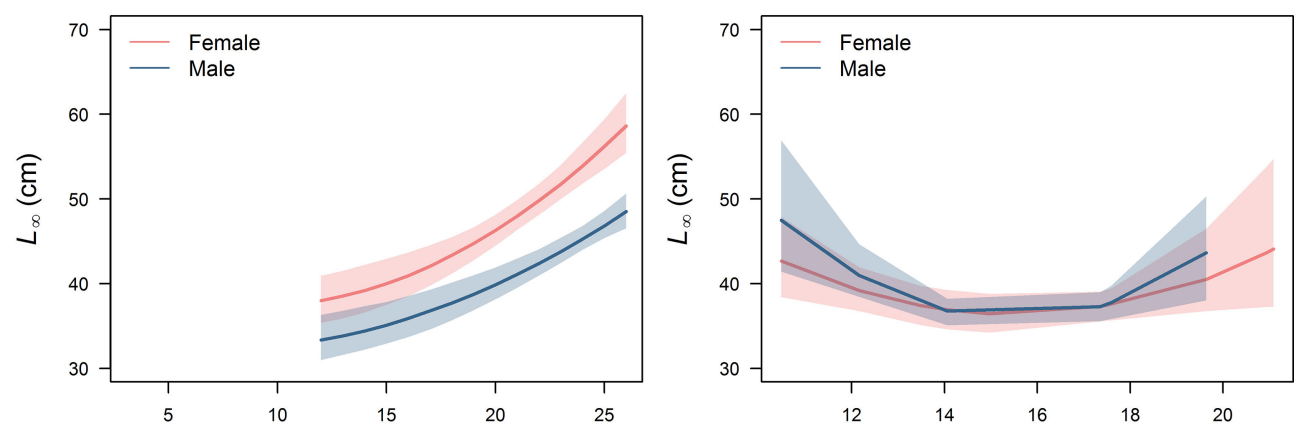

C

$\mathbf{F}$
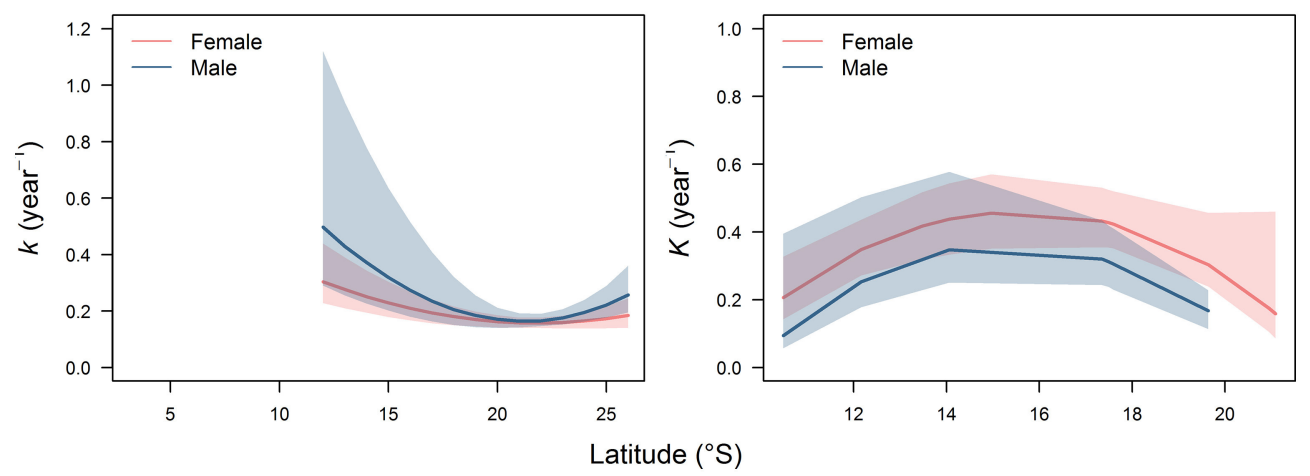

FIGURE 5 | Latitudinal trends in residual length-at-age (A,D) and von Bertalanffy growth parameters $L_{\infty} \mathbf{( B , E )}$ and $k(\mathbf{C}, \mathbf{F})$ for male and female Etelis carbunculus from the Pacific and Indian Oceans. Shaded areas indicate $95 \%$ confidence intervals.

dating, and thus provide the first reliable estimates of growth for E. carbunculus. We found evidence for significant variation in growth of E. carbunculus between oceans and sexes, and across latitudes, although spatial variation in growth was larger than the variation between sexes. The average maximum length of female and male E. carbunculus varied up to $50 \%$ with latitude, with the largest fish sampled at the highest latitudes $\left(>20^{\circ} \mathrm{S}\right)$ and the smallest fish at lower latitudes $\left(\sim 12-20^{\circ} \mathrm{S}\right)$. However, relative growth rates $(k)$ were generally lower at higher latitudes than at lower latitudes. The average maximum length was 35\% longer for females and $20 \%$ longer for males in the Pacific Ocean than in the Indian Ocean, but relative growth rates were slower in the Pacific Ocean compared with the Indian Ocean. The magnitude of spatial variation in growth observed for E. carbunculus was comparable to that observed for other shallow water tropical species at similar spatial scales (e.g., Meekan et al., 2001; Robertson et al., 2005; Berumen et al., 2012; Cappo et al., 2013), suggesting that the forces structuring local adaptation in growth can operate at similar spatial scales for tropical shallow and deepwater demersal species.

The observed latitudinal gradient in growth of E. carbunculus in the Pacific Ocean is consistent with the temperature-size rule, based on the metabolic theory of ecology (MTE, Atkinson, 1994; Brown et al., 2004), which predicts that fish at higher latitudes, where water temperature is cooler, will reach larger maximum sizes and exhibit lower initial growth rates. Larger maximum size at higher latitudes has been a common observation for many tropical shallow water species with distributions that span significant latitudinal ranges and temperature gradients (e.g., Berumen et al., 2012; Cappo et al., 2013). Departures from 
TABLE 5 | Summary of von Bertalanffy growth models used to examine latitudinal variation in growth parameters $k$ and $L_{\infty}$ for female and male Etelis carbunculus in the Pacific and Indian Oceans.

\begin{tabular}{|c|c|c|c|c|c|c|c|c|c|c|}
\hline \multirow[b]{2}{*}{ Ocean } & \multicolumn{2}{|c|}{ Latitudinal functions } & \multicolumn{4}{|c|}{ Female } & \multicolumn{4}{|c|}{ Male } \\
\hline & $f_{1}$ & $f_{2}$ & RSS & $\mathrm{AlC}_{\mathrm{C}}$ & $\Delta \mathrm{AlC}_{\mathrm{c}}$ & $w$ & RSS & $\mathrm{AIC}_{\mathrm{c}}$ & $\Delta \mathrm{AIC}_{\mathrm{c}}$ & $w$ \\
\hline \multirow[t]{9}{*}{ Pacific } & $L_{\infty}+\alpha_{1} \bullet$ lat $+\alpha_{2} \bullet$ lat $^{2}$ & $k+\beta_{1} \bullet$ lat $+\beta_{2} \bullet$ lat $^{2}$ & 4386.7 & 1160.5 & 0 & 0.96 & 1100.9 & 450.1 & 0 & 0.66 \\
\hline & $L_{\infty}+\alpha_{1} \cdot$ lat $+\alpha_{2} \cdot$ lat $^{2}$ & $k+\beta_{1} \cdot$ lat & 4538.7 & 1167.1 & 6.6 & 0.03 & 1125.5 & 451.9 & 1.8 & 0.27 \\
\hline & $L_{\infty}+\alpha_{1} \cdot$ lat $+\alpha_{2} \cdot$ lat $^{2}$ & $k$ & 4693.1 & 1173.7 & 13.2 & 0 & 1254.2 & 460.9 & 10.8 & 0 \\
\hline & $L_{\infty}+\alpha_{1} \bullet$ lat & $k+\beta_{1} \bullet l a t+\beta_{2} \bullet l a t^{2}$ & 4689.6 & 1173.5 & 13.0 & 0 & 1163.6 & 454.7 & 4.6 & 0.07 \\
\hline & $L_{\infty}+\alpha_{1} \bullet$ lat & $k+\beta_{1} \bullet$ lat & 5675.4 & 1210.7 & 50.2 & 0 & 1681.0 & 485.2 & 35.1 & 0 \\
\hline & $L_{\infty}+\alpha_{1} \cdot$ lat & $k$ & 5696.8 & 1211.5 & 51.0 & 0 & 1733.2 & 487.8 & 37.7 & 0 \\
\hline & $L_{\infty}$ & $k+\beta_{1} \bullet$ lat $+\beta_{2} \bullet$ lat $^{2}$ & 5521.9 & 1205.4 & 44.9 & 0 & 1642.5 & 483.3 & 33.2 & 0 \\
\hline & $L_{\infty}$ & $k+\beta_{1} \bullet$ lat & 6033.9 & 1222.7 & 62.2 & 0 & 1992.9 & 499.4 & 49.3 & 0 \\
\hline & $L_{\infty}$ & $k$ & 6352.5 & 1232.7 & 72.2 & 0 & 2050.2 & 501.7 & 51.6 & 0 \\
\hline \multirow[t]{9}{*}{ Indian } & $L_{\infty}+\alpha_{1} \cdot$ lat $+\alpha_{2} \cdot$ lat $^{2}$ & $k+\beta_{1} \bullet \mathrm{lat}+\beta_{2} \bullet \mathrm{lat} t^{2}$ & 369.8 & 186.0 & 0 & 0.35 & 122.1 & 100.1 & 0 & 0.38 \\
\hline & $L_{\infty}+\alpha_{1} \bullet$ lat $+\alpha_{2} \bullet$ lat $^{2}$ & $k+\beta_{1} \cdot$ lat & 393.2 & 188.2 & 2.2 & 0.12 & 124.8 & 100.6 & 0.5 & 0.30 \\
\hline & $L_{\infty}+\alpha_{1} \cdot$ lat $+\alpha_{2} \cdot$ lat $^{2}$ & $k$ & 411.3 & 189.9 & 3.9 & 0.05 & 152.1 & 105.0 & 4.9 & 0.03 \\
\hline & $L_{\infty}+\alpha_{1} \bullet$ lat & $k+\beta_{1} \bullet \mathrm{lat}+\beta_{2} \bullet \mathrm{lat}^{2}$ & 394.0 & 188.3 & 2.3 & 0.11 & 137.6 & 102.8 & 4.9 & 0.03 \\
\hline & $L_{\infty}+\alpha_{1} \bullet$ lat & $k+\beta_{1} \bullet$ lat & 396.6 & 188.5 & 2.5 & 0.10 & 138.6 & 102.9 & 2.8 & 0.09 \\
\hline & $L_{\infty}+\alpha_{1} \cdot$ lat & $k$ & 411.3 & 189.9 & 3.9 & 0.05 & 154.1 & 105.3 & 5.2 & 0.03 \\
\hline & $L_{\infty}$ & $k+\beta_{1} \cdot \mathrm{lat}+\beta_{2} \bullet \mathrm{lat} t^{2}$ & 397.9 & 188.7 & 2.7 & 0.09 & 144.3 & 103.8 & 3.7 & 0.06 \\
\hline & $L_{\infty}$ & $k+\beta_{1} \bullet$ lat & 404.2 & 189.2 & 3.2 & 0.07 & 145.2 & 103.9 & 3.8 & 0.06 \\
\hline & $L_{\infty}$ & $k+\beta_{1} \bullet$ lat & 411.3 & 189.9 & 3.9 & 0.05 & 160.5 & 106.1 & 6.0 & 0.02 \\
\hline
\end{tabular}

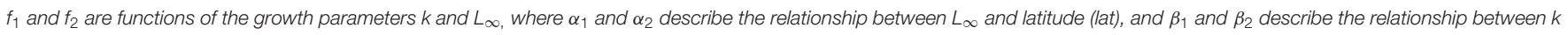

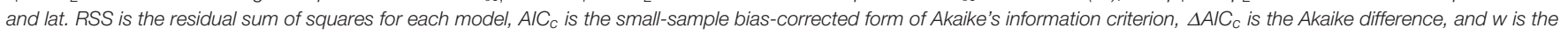
Akaike weight.

TABLE 6 | Estimates of total mortality $(Z)$, natural mortality $(M)$, fishing mortality $(F)$, and exploitation ratio $(E)$ for female and male Etelis carbunculus from the Pacific and Indian Oceans.

\begin{tabular}{llllll}
\hline Ocean & Sex & $\boldsymbol{Z}( \pm$ s.e.) & $\boldsymbol{M}$ & $\boldsymbol{F}$ (士s.e.) & $\boldsymbol{E}( \pm$ s.e.) \\
\hline Pacific & Female & $0.27(0.03)$ & 0.17 & $0.10(0.03)$ & $0.37(0.04)$ \\
& Male & $0.18(0.01)$ & 0.14 & $0.04(0.01)$ & $0.22(0.01)$ \\
\hline \multirow{2}{*}{ Indian } & Female & $0.30(0.09)$ & 0.20 & $0.10(0.09)$ & $0.33(0.13)$ \\
& Male & $0.16(0.04)$ & 0.13 & $0.03(0.04)$ & $0.19(0.06)$ \\
\hline
\end{tabular}

growth patterns predicted by MTE have also been observed, including the converse relationship between growth and latitude (Cossington et al., 2010), or a parabolic relationship with reduced growth performance toward the extents of a species' latitudinal distribution (i.e., edge of range effects, Wakefield et al., 2017b). Although, deepwater snapper typically occupy depths from 100 to $400 \mathrm{~m}$, where the ambient temperature is cooler than surface waters, the strength of the temperature gradient across tropical latitudes at these depths is of a similar magnitude to that experienced by shallow water species in $<50 \mathrm{~m}$ water depth (Roemmich and Gilson, 2009). Therefore, temperature is likely contributing to the observed latitudinal variation in growth of E. carbunculus in the Pacific Ocean. A similar trend was not observed in the Indian Ocean due to a lack of samples from latitudes $>20^{\circ} \mathrm{S}$. This might at least partially explain the observed differences in growth between oceans, as fish $>50 \mathrm{~cm} F L$ in the Pacific Ocean were only sampled from latitudes $>20^{\circ}$ S. Wakefield et al. (2013b) observed a similar latitudinal pattern in the Indian Ocean for the deepwater grouper Hyporthodus octofasciatus, with a significantly larger length-atage at higher latitudes. Analyses of growth for E. carbunculus from 1) latitudes south of $20^{\circ} \mathrm{S}$ in the Indian Ocean, and 2) its latitudinal distribution in the northern Pacific Ocean, would clarify whether the relationship between growth and latitude are consistent with those observed in the south Pacific Ocean.

Female E. carbunculus reached a larger maximum length than males in the Pacific Ocean, but growth patterns were similar between sexes in the Indian Ocean. The larger observed lengthat-age for female E. carbunculus compared to males in the Pacific Ocean contrasts with the general trend for Lutjanidae species in the Indo-Pacific region, where typically males grow to larger sizes than females (Newman et al., 1996b, 2000a, 2016; Kritzer, 2004; Heupel et al., 2010) or there are no detectable differences in growth between sexes (Newman et al., 2000b, 2016; Newman and Dunk, 2003; Marriott et al., 2007). The larger maximum length for females could be explained by a trade-off between reproductive potential (gonad weight) and mortality. The energetic costs associated with producing sperm are lower than for eggs (Wootton, 1985), providing a mechanism for males to allocate more energy into somatic growth and attain a larger size than females. Hence, for females to reach a larger maximum size than males, they would require a higher food intake and/or greater foraging activity, exposing them to a greater mortality risk due to increased encounters with predators and diseases (Roff, 1983). The tradeoff, however, is that reproductive output can be increased at larger sizes, thus compensating for this 


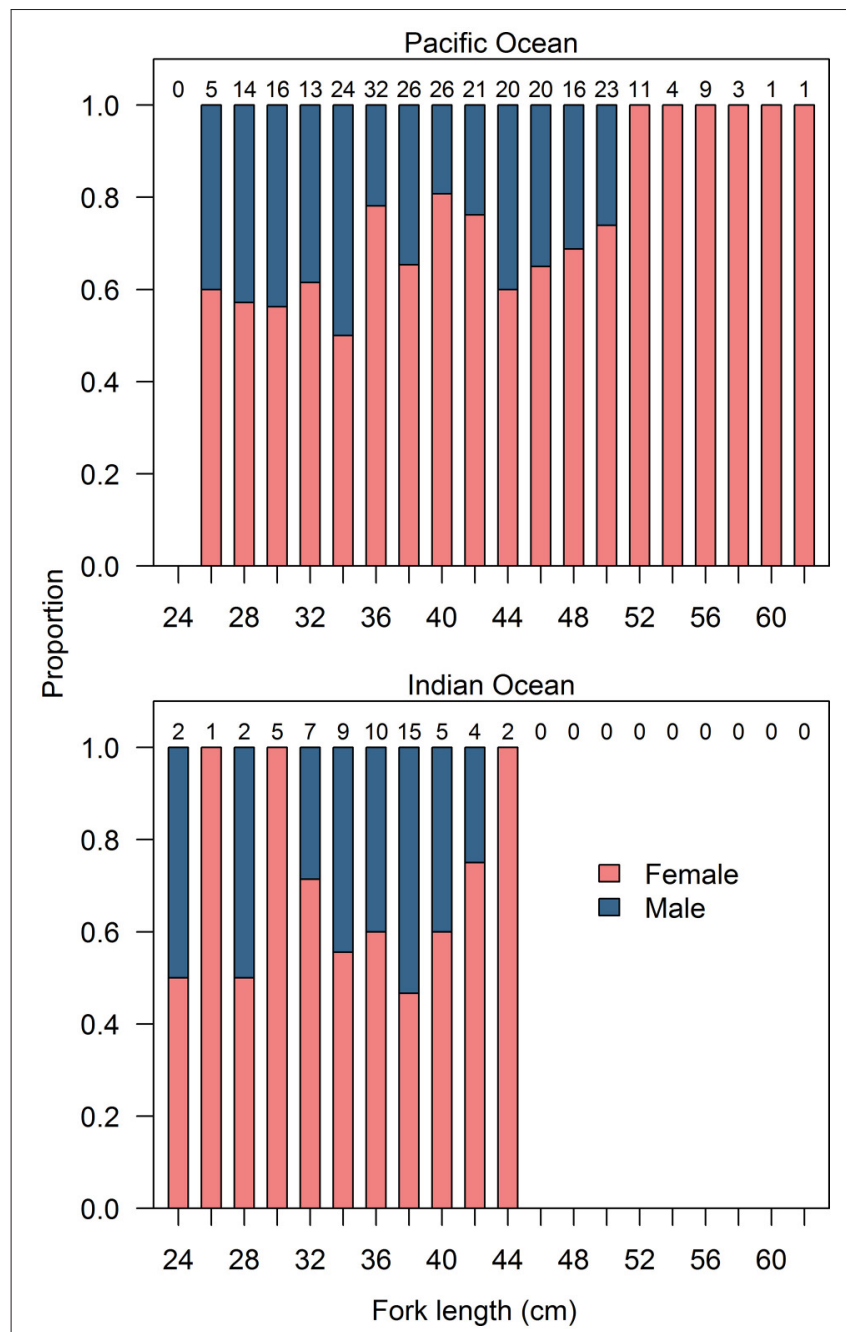

FIGURE 6 | Proportion of female and male Etelis carbunculus by fork length in the Pacific and Indian Oceans. Total sample sizes are indicated above each bar.

higher mortality risk. The significant increase in female gonad weight with whole fish weight, and the higher natural mortality rates observed for female E. carbunculus in both the Pacific and Indian Oceans, is consistent with this hypothesis. Furthermore, assuming the sex ratios of E. carbunculus populations are at or close to unity, the significant female bias in our samples suggests that females have a higher propensity to take baited fishing gear, supporting the hypothesis that females forage more actively than males.

Information on the reproductive mode and spawning season for deepwater snappers is limited (Newman et al., 2016). We observed that E. carbunculus is a gonochore with a protracted spawning season in the Pacific Ocean from late spring to autumn, with peak spawning in the summer months. This is consistent with knowledge of deepwater snapper species to date (Newman et al., 2016) and with observations of E. carbunculus in Hawaiian waters (Everson, 1984). Further analysis of gonad samples from the Indian Ocean is required to determine if the spawning season
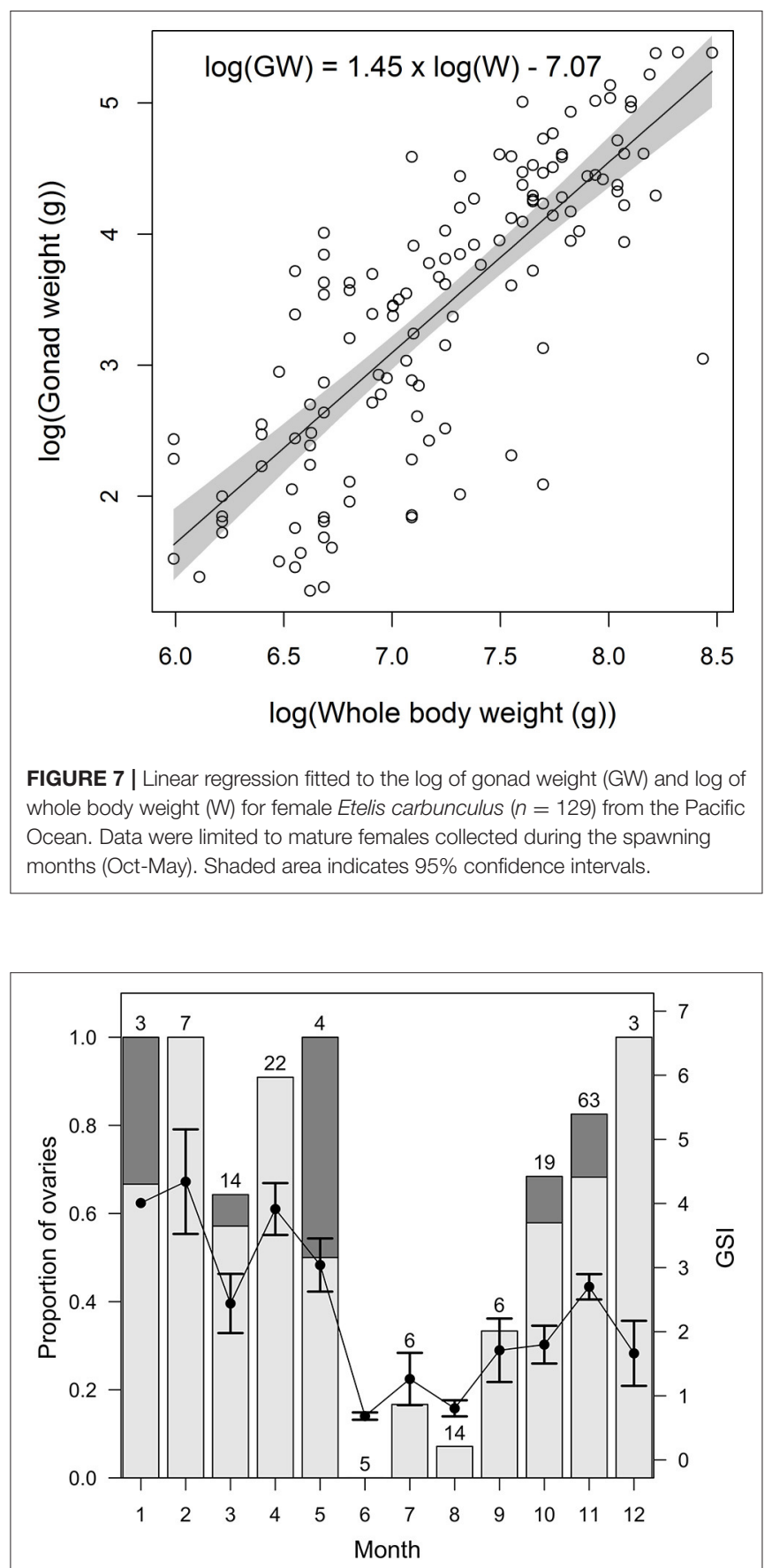

FIGURE 8 | Mean monthly gonadosomatic indices (GSI \pm s.e.) and the percentage of all ovaries at stage III (light gray bars), IV, and V (dark gray bars) of female Etelis carbunculus from the Pacific Ocean. Data were limited to mature females. Sample sizes are shown for each month.

is similar across ocean basins. A protracted spawning season coupled with a long larval duration (Leis and Lee, 1994) likely facilitates wide-spread mixing of E. carbunculus resulting in the observed genetic homogeneity among populations throughout the Pacific Ocean (Andrews et al., 2014; Goldstien et al., 2015). It is likely, therefore, that many nations are exploiting the same 

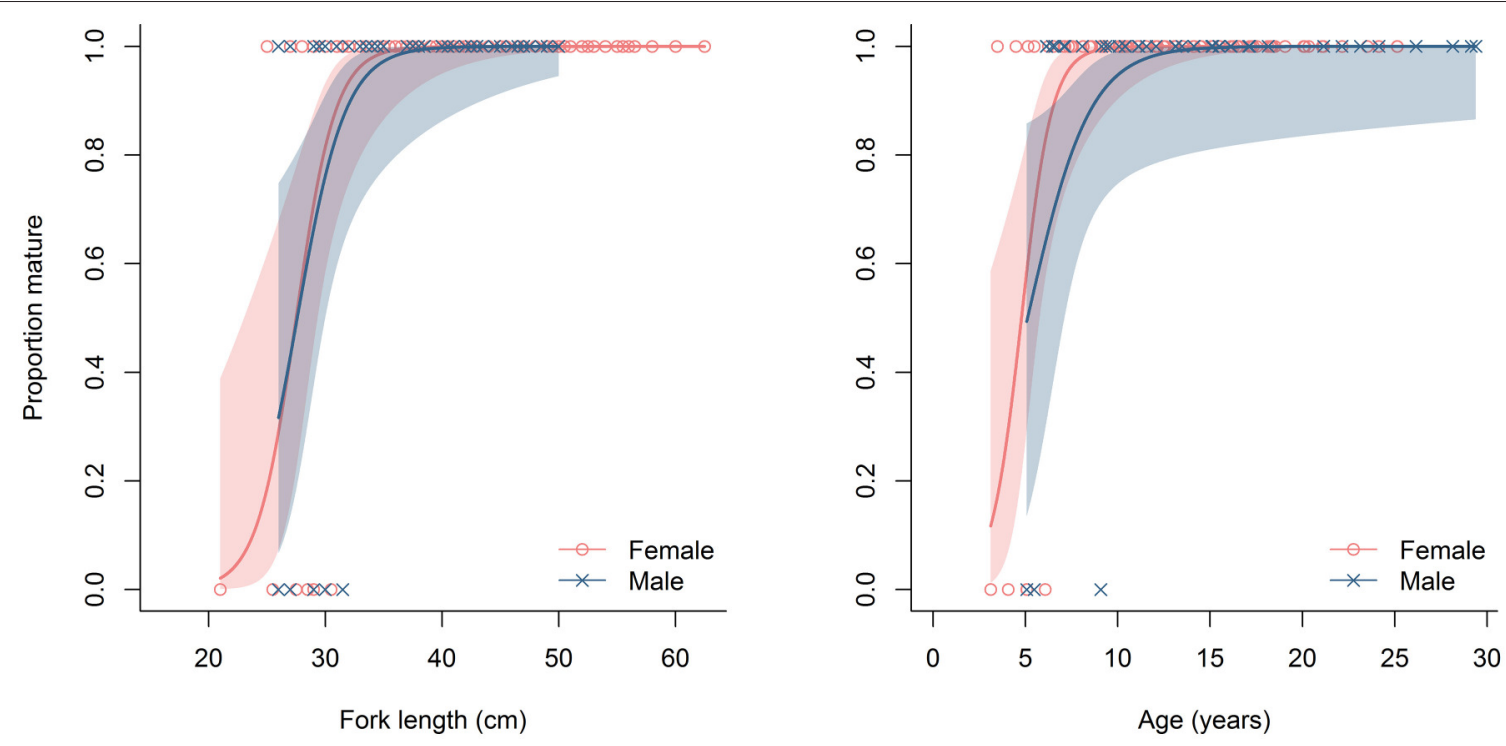

FIGURE 9 | Estimated proportion of mature female and male Etelis carbunculus by fork length and age from the Pacific Ocean. Data were limited to individuals collected during the spawning months (Oct-May). Shaded areas indicate 95\% confidence intervals.

stocks of E. carbunculus, and there is a need for collaboration among countries to optimize management of this species.

Our estimates of the length at which $50 \%$ of female and male E. carbunculus attain maturity $(27.5 \mathrm{~cm} \mathrm{FL}$ and $27.6 \mathrm{~cm}$ $F L$, respectively) are remarkably similar to the estimates of 27.8 and $27.9 \mathrm{~cm}$ for females from Hawaii (DeMartini and Lau, 1999), suggesting spatial variability in length-based maturity schedules of E. carbunculus may be small. Relative to their mean asymptotic length $\left(L_{\infty}\right)$, the length at which $50 \%$ of females and males attained maturity was 54 and $61 \%$ respectively, which is relatively high, but within the range of other deepwater snappers (Newman et al., 2016). Minimum size limits are a common management measure in fisheries, and are often based on maturity schedules and objectives related to minimizing risks of growth and recruitment overfishing by allowing a proportion of the stock to reproduce prior to becoming vulnerable to fishing mortality (Coggins et al., 2007; Gwinn et al., 2015). For deepwater snapper, including E. carbunculus, the effectiveness of minimum size limits is likely to be severely compromised by high rates of post-release mortality (O'Malley, 2015). However, the low proportion $(\sim 6 \%)$ of fish in size classes less than the length at $50 \%$ maturity in our samples suggests that the fishing gear used currently to target deepwater snappers is unlikely to impact significantly on the immature component of E. carbunculus populations. Moreover, previous estimates of spawning biomass per recruit in Eteline snappers (Williams et al., 2013) were found to be more sensitive to variations in mortality than to age at first capture, suggesting that regulating fishing mortality rather than gear selectivity would be a more effective management approach for these species.

For data-poor fisheries, such as most fisheries targeting deepwater snappers in the Pacific and Indian Oceans, the development and implementation of harvest strategies often requires the use of proxies for target and limit reference points (Dowling et al., 2015a). In the absence of information to estimate maximum sustainable yield (MSY) reliably, a ratio of fishing mortality to natural mortality of 0.5 (i.e., $E=0.5$ ) has been proposed as an approximation for the fishing mortality that would achieve MSY ( $F_{\text {MSY }}$ ) (Alverson and Pereyra, 1969). In a review of indicators for measuring the impacts of fishing, Rochet and Trenkel (2003) suggest that $E=0.5$ should be applied as a limit reference point, above which a stock would be considered subject to overfishing. All of the estimates of $E$ for E. carbunculus were $<0.5$, suggesting that stocks in the Pacific and Indian Oceans are not currently being overfished. However, the estimates of $E$ for females were higher than for males in both the Pacific and Indian Oceans, indicating greater fishing pressure on females than males. This observation is likely due to the larger size-at-age of females compared to males, assuming that selectivity of the fishing gear is related directly to fish size. The significant female bias and increase in female bias with length supports this explanation. Prior to establishing exploitation rates as proxy reference points for the management of deepwater snapper fisheries, it will be highly desirable to evaluate them through formal management strategy evaluation to ensure that they will achieve the objectives set for the fishery (Dowling et al., 2015a).

Fisheries data throughout the Indo-Pacific region have not distinguished between E. carbunculus and E. sp., as they were thought to comprise a single species. Consequently, catch data have been reported as the single species E. carbunculus. Our results reveal substantial differences in biology between E. carbunculus and E. sp. (Williams et al., 2013, 2015), which emphasize the importance of distinguishing between the two species in fisheries catch data. For example, the maximum observed length and weight for E. carbunculus $(62 \mathrm{~cm} \mathrm{FL}$, 
$4.8 \mathrm{~kg}$ ) is much smaller than for E. sp. (>100 cm FL, $>20 \mathrm{~kg}$; Williams et al., 2013). However, there is a smaller difference in the maximum reported age between E. carbunculus (32 years) and E. sp. (43 years; Williams et al., 2015), indicating substantial differences in growth trajectories between the two species. Estimates of biological parameters are fundamental to most stock assessments, and combining species with divergent life histories into a single species assessment model would result in strong biases in estimates of biomass and sustainable harvest rates (Maunder and Piner, 2014). Therefore, differentiating E. carbunculus and $E$. sp. in fisheries catch data will be important to avoid potential biases in assessments. Identifying these two species can now be achieved accurately using external features (Andrews et al., 2016) or by using otolith shape where whole fish are unavailable and otoliths can be or have already been extracted (Wakefield et al., 2014).

\section{CONCLUSION}

E. carbunculus and other deepwater snapper species support important fisheries in many developing countries where resources are limited and fisheries statistics required for traditional stock assessments are not often available. Our preliminary results suggest that $E$. carbunculus might not be currently subject to overfishing in the Indo-Pacific region as a whole. However, more detailed assessments will be required to assess the status of stocks more thoroughly. Importantly, the life history information described in this study provides the foundation for the development of the first species-specific assessment models and harvest strategies for E. carbunculus. Recent advances in the development of data-poor assessment methods highlight the utility of obtaining accurate life history information, such as growth and maturity, for parameterizing assessment models for data-poor fisheries (e.g., Dowling et al., 2015b; Hordyk et al., 2015). Our results indicate that assessments would benefit from explicit consideration of spatial variation in

\section{REFERENCES}

Adams, S. (2003). Morphological ontogeny of the gonad of three plectropomid species through sex differentiation and transition. J. Fish Biol. 63, 22-36. doi: 10.1046/j.1095-8649.2003.00098.x

Alverson, D. L., and Pereyra, W. T. (1969). Demersal fish explorations in the northeastern Pacific Ocean - an evaluation of exploratory fishing methods and analytical approaches to stock size and yield forecasts. J. Fish. Res. Board Can. 26, 1985-2001. doi: 10.1139/f69-188

Andrews, A. H., Kalish, J. M., Newman, S. J., and Johnston, J. M. (2011). Bomb radiocarbon dating of three important reef-fish species using Indo-Pacific $\Delta$ 14C chronologies. Mar. Freshw. Res. 62, 1259-1269. doi: 10.1071/MF11080

Andrews, K. R., Moriwake, V. N., Wilcox, C., Grau, E. G., Kelley, C., Pyle, R. L., et al. (2014). Phylogeographic analyses of submesophotic snappers Etelis coruscans and Etelis "marshi" (Family Lutjanidae) reveal concordant genetic structure across the Hawaiian Archipelago. PLoS ONE 9:e91665. doi: 10.1371/journal.pone.0091665

Andrews, K. R., Williams, A. J., Fernandez-Silva, I., Newman, S. J., Copus, J. M., Wakefield, C. B., et al. (2016). Phylogeny of deepwater snappers (Genus Etelis) reveals a cryptic species pair in the Indo-Pacific and Pleistocene invasion of the Atlantic. Mol. Phylogenet. Evol. 100, 361-371. doi: 10.1016/j.ympev.2016.04.004 the biology of E. carbunculus and sex-specific growth curves. Such structural improvements are likely to provide more reliable estimates of biomass, fishing mortality and potential yields, and ultimately provide the foundation for more robust management decisions.

\section{AUTHOR CONTRIBUTIONS}

$\mathrm{AW}, \mathrm{CW}, \mathrm{SJNi}$, and SJNe contributed to the conception and design of the work. TH, JK, EV, AW, and CW were responsible for collection and processing of biological samples and associated data. AW, CW, and FA contributed to the analysis of the data. AW, CW, SJNe, EV, FA, TH, JK, and SJNi contributed to the interpretation of the analyses and to drafting and editing the manuscript.

\section{ACKNOWLEDGMENTS}

The authors extend their gratitude to fishers and colleagues for their assistance with the collection of samples. Logistic and financial support for this study was provided by the Pacific Community (New Caledonia) and the Department of Primary Industries and Regional Development, Government of Western Australia. Funding for the collection of samples in the Pacific region was provided by the Australian Agency for International Development (AusAID), the French Pacific Fund, and the Zone Économique de Nouvelle-Calédonie (ZoNéCo) Programme. FA was funded by a Marie Curie Intra-European Fellowship. Thank you to the reviewers for their constructive comments on earlier versions of this manuscript.

\section{SUPPLEMENTARY MATERIAL}

The Supplementary Material for this article can be found online at: https://www.frontiersin.org/articles/10.3389/fmars. 2017.00382/full\#supplementary-material

Atkinson, D. (1994). Temperature and organism size - a biological law for ectotherms? Adv. Ecol. Res. 25, 1-58. doi: 10.1016/S0065-2504(08)60212-3

Beamish, R. J., and Fournier, D. A. (1981). A method for comparing the precision of a set of age determinations. Can. J. Fish. Aquat. Sci. 38, 982-983. doi: $10.1139 /$ f81-132

Berumen, M. L., Trip, E. D. L., Pratchett, M. S., and Choat, J. H. (2012). Differences in demographic traits of four butterflyfish species between two reefs of the Great Barrier Reef separated by 1,200 km. Coral Reefs 31, 169-177. doi: 10.1007/s00338-011-0838-z

Brown, J. H., Gillooly, J. F., Allen, A. P., Savage, V. M., and West, G. B. (2004). Toward a metabolic theory of ecology. Ecology 85, 1771-1789. doi: 10.1890/03-9000

Burnham, K. P., and Anderson, D. R. (2002). Model Selection and Multimodel Inference: A Practical Information-Theoretic Approach, 2nd Edn. New York, NY: Springer.

Cappo, M., Marriott, R. J., and Newman, S. J. (2013). James's rule and causes and consequences of a latitudinal cline in the demography of John's Snapper (Lutjanus johnii) in coastal waters of Australia. Fish. Bull. 111, 309-324. doi: 10.7755/FB.111.4.2

Carter, A. B., Davies, C. R., Mapstone, B. D., Russ, G. R., Tobin, A. J., and Williams, A. J. (2014a). Effects of region, demography, and protection from fishing on 
batch fecundity of common coral trout (Plectropomus leopardus). Coral Reefs 33, 751-763. doi: 10.1007/s00338-014-1164-z

Carter, A. B., Russ, G. R., Tobin, A. J., Williams, A. J., Davies, C. R., and Mapstone, B. D. (2014b). Spatial variation in the effects of size and age on reproductive dynamics of common coral trout Plectropomus leopardus. J. Fish Biol. 84, 1074-1098. doi: 10.1111/jfb.12346

Choat, J. H., Robertson, D. R., Ackerman, J. L., and Posada, J. M. (2003). An age-based demographic analysis of the Caribbean stoplight parrotfish Sparisoma viride. Mar. Ecol. Prog. Ser. 246, 265-277. doi: 10.3354/meps 246265

Coggins, L. G., Catalano, M. J., Allen, M. S., Pine, W. E., and Walters, C. J. (2007). Effects of cryptic mortality and the hidden costs of using length limits in fishery management. Fish Fish. 8, 196-210. doi: 10.1111/j.1467-2679.2007. 00247.x

Conover, D. O., Clarke, L. M., Munch, S. B., and Wagner, G. N. (2006). Spatial and temporal scales of adaptive divergence in marine fishes and the implications for conservation. J. Fish Biol. 69, 21-47. doi: 10.1111/j.1095-8649.2006.01274.x

Cossington, S., Hesp, S. A., Hall, N. G., and Potter, I. C. (2010). Growth and reproductive biology of the foxfish Bodianus frenchii, a very long-lived and monandric protogynous hermaphroditic labrid. J. Fish Biol. 77, 600-626. doi: $10.1111 / j .1095-8649.2010 .02706 . x$

Dalzell, P., Adams, T. J. H., and Polunin, N. V. C. (1996). Coastal fisheries in the Pacific Islands. Oceanogr. Mar. Biol. 34, 395-531.

Dalzell, P., and Preston, G. L. (1992). Deep Reef Slope Fishery Resources Of The South Pacific: A Summary and Analysis Of The Dropline Fishing Survey Data Generated by the Activities of the SPC Fisheries Programme between 1974 and 1988. Inshore Fisheries Research Project, Technical Document No. 2. South Pacific Commission, Noumea.

DeMartini, E. E., and Lau, B. B. (1999). Morphometric criteria for estimating sexual maturity in two snappers, Etelis carbunculus and Pristipomoides sieboldii. Fish. Bull. 97, 449-458.

Dowling, N. A., Dichmont, C. M., Haddon, M., Smith, D. C., Smith, A. D. M., and Sainsbury, K. (2015a). Empirical harvest strategies for data-poor fisheries: a review of the literature. Fish. Res. 171, 141-153. doi: 10.1016/j.fishres.2014.11.005

Dowling, N. A., Dichmont, C. M., Haddon, M., Smith, D. C., Smith, A. D. M., and Sainsbury, K. (2015b). Guidelines for developing formal harvest strategies for data-poor species and fisheries. Fish. Res. 171, 130-140. doi: 10.1016/j.fishres.2014.09.013

Everson, A. R. (1984). "Spawning and gonadal maturation of the ehu, Etelis carbunculus, in the Northwestern Hawaiian Islands," in Proceedings of the Second Symposium on Resource Investigations in the Northwestern Hawaiian Islands, Vol 2, eds R. W. Grigg and K. Y. Tanoue (Honolulu, HI: University of Hawaii), 128-148. UNIHI-SEAGRANT-MR-84-01.

Ferreira, B. P. (1995). Reproduction in the common coral trout Plectropomus leopardus from the central and northern Great Barrier Reef. Bull. Mar. Sci. 56, 653-669.

Gaither, M. R., Jones, S. A., Kelley, C., Newman, S. J., Sorenson, L., and Bowen, B. W. (2011). High connectivity in the deepwater snapper Pristipomoides filamentosus (Lutjanidae) across the Indo-Pacific with isolation of the Hawaiian Archipelago. PLoS ONE 6:e28913. doi: 10.1371/journal.pone.0028913

Gauldie, R. W., Davies, N. M., Coote, G., and Vickridge, I. (1990). The relationship between organic material and check rings in fish otoliths. Comp. Biochem. Physiol. B 97A, 461-474. doi: 10.1016/0300-9629(90)90112-6

Goldstien, S., Williams, A., Nicol, S., Kraberger, S., and Stainton, D. (2015). The Genetic Distribution Of Three Deepwater Snappers in the Western and Central Pacific Ocean. SPC Fisheries Newsletter No. 148. Secretariat of the Pacific Community, Noumea.

Grubert, M. A., Saunders, T. M., Martin, J. M., Lee, H. S., and Walters, C. J. (2013). Stock Assessments of Selected Northern Territory Fishes. Fishery Report 110, Northern Territory Government, Darwin.

Gust, N., Choat, J. H., and Ackerman, J. L. (2002). Demographic plasticity in tropical reef fishes. Mar. Biol. 140, 1039-1051. doi: 10.1007/s00227-0010773-6

Gwinn, D. C., Allen, M. S., Johnston, F. D., Brown, P., Todd, C. R., and Arlinghaus, R. (2015). Rethinking length-based fisheries regulations: the value of protecting old and large fish with harvest slots. Fish Fish. 16, 259-281. doi: $10.1111 /$ faf. 12053
Heupel, M. R., Williams, A. J., Welch, D. J., Davies, C. R., Penny, A., Kritzer, J. P., et al. (2010). Demographic characteristics of exploited tropical lutjanids: a comparative analysis. Fish. Bull. 108, 420-432. Available online at: https://www. st.nmfs.noaa.gov/spo/FishBull/1084/heupel.pdf

Hilborn, R., and Walters, C. J. (2013). Quantitative Fisheries Stock Assessment: Choice, Dynamics and Uncertainty. Dordrecht: Springer Science and Business Media.

Hill, N., Nicol, S., Peatman, T., Halafihi, T., and Williams, A. (2015). Application of a Harvest Strategy to a Resource-Limited Deepwater Snapper Fishery. SPC Fisheries Newsletter. Noumea: The Pacific Community.

Hoenig, J. M. (1983). Empirical use of longevity data to estimate mortality rates. Fish. Bull. 82, 898-902.

Hordyk, A. R., Loneragan, N. R., and Prince, J. D. (2015). An evaluation of an iterative harvest strategy for data-poor fisheries using the length-based spawning potential ratio assessment methodology. Fish. Res. 171, 20-32. doi: 10.1016/j.fishres.2014.12.018

Kennington, W. J., Keron, P. W., Harvey, E. S., Wakefield, C. B., Williams, A. J., Halafihi, T., et al. (2017). High intra-ocean, but limited interocean genetic connectivity in populations of the deep-water oblique-banded snapper Pristipomoides zonatus (Pisces: Lutjanidae). Fish. Res. 193, 242-249. doi: 10.1016/j.fishres.2017.04.015

Kimura, D. K. (2008). Extending the von Bertalanffy growth model using explanatory variables. Can. J. Fish. Aquat. Sci. 65, 1879-1891. doi: 10.1139/F08-091

Koslow, J. A., Boehlert, G. W., Gordon, J. D. M., Haedrich, R. L., Lorance, P., and Parin, N. (2000). Continental slope and deep-sea fisheries: implications for a fragile ecosystem. ICES J. Mar. Sci. 57, 548-557. doi: 10.1006/jmsc.2000.0722

Kritzer, J. P. (2002). Variation in the population biology of stripey bass Lutjanus carponotatus within and between two island groups on the Great Barrier Reef. Mar. Ecol. Prog. Ser. 243, 191-207. doi: 10.3354/meps 243191

Kritzer, J. P. (2004). Sex-specific growth and mortality, spawning season, and female maturation of the stripey bass (Lutjanus carponotatus) on the Great Barrier Reef. Fish. Bull. 102, 94-107.

Kritzer, J. P., and Sale, P. F. (2006). Marine Metapopulations. New York, NY: Academic Press.

Leis, J. M., and Lee, K. (1994). Larval development in the lutjanid subfamily Etelinae (Pisces): the genera Aphareus, Aprion, Etelis and Pristipomoides. Bull. Mar. Sci. 55, 46-125.

Loeun, K. L., Goldstien, S., Gleeson, D., Nicol, S. J., and Bradshaw, C. J. A. (2014). Limited genetic structure among broad-scale regions for two commercially harvested, tropical deepwater snappers in New Caledonia. Fish. Sci. 80, 13-19. doi: 10.1007/s12562-013-0673-y

Marriott, R. J., Mapstone, B. D., and Begg, G. A. (2007). Age-specific demographic parameters, and their implications for management of the red bass, Lutjanus bohar (Forsskal 1775): a large, long-lived reef fish. Fish. Res. 83, 204-215. doi: 10.1016/j.fishres.2006.09.016

Maunder, M. N., and Piner, K. R. (2014). Contemporary fisheries stock assessment: many issues still remain. ICES J. Mar. Sci. 72, 7-18. doi: 10.1093/icesjms/fsu015

Meekan, M. G., Ackerman, J. L., and Wellington, G. M. (2001). Demography and age structures of coral reef damselfishes in the tropical eastern Pacific Ocean. Mar. Ecol. Prog. Ser. 212, 223-232. doi: 10.3354/meps212223

Millar, R. B. (2015). A better estimator of mortality rate from age-frequency data. Can. J. Fish. Aquat. Sci. 72, 364-375. doi: 10.1139/cjfas-2014-0193

Molony, B. W., Newman, S. J., Joll, L., Lenanton, R. C. J., and Wise, B. (2011). Are Western Australian waters the least productive waters for finfish across two oceans? A review with a focus on finfish resources in the Kimberley region and north coast bioregion. J. R. Soc. West. Aust. 94, 323-332. Available online at: https://www.rswa.org.au/publications/Journal/94(2)/Molonyetal.pp. 323-332.pdf

Morato, T., Watson, R., Pitcher, T. J., and Pauly, D. (2006). Fishing down the deep. Fish Fish. 7, 24-34. doi: 10.1111/j.1467-2979.2006.00205.x

Newman, S. J., Cappo, M., and Williams, D. M. (2000a). Age, growth and mortality of the stripey, Lutjanus carponotatus (Richardson) and the brownstripe snapper, L. vitta (Quoy and Gaimard) from the central Great Barrier Reef, Australia. Fish. Res. 48, 263-275. doi: 10.1016/S0165-7836(00) 00184-3

Newman, S. J., Cappo, M., and Williams, D. M. (2000b). Age, growth, mortality rates and corresponding yield estimates using otoliths of the tropical red 
snappers, Lutjanus erythropterus, L. malabaricus, and L. sebae, from the Central Great Barrier Reef. Fish. Res. 48, 1-14. doi: 10.1016/S0165-7836(00)00115-6

Newman, S. J., and Dunk, I. J. (2003). Age validation, growth, mortality, and additional population parameters of the goldband snapper (Pristipomoides multidens) off the Kimberley coast of northwestern Australia. Fish. Bull. 101, 116-128. Available online at: https://www.st.nmfs.noaa.gov/spo/FishBull/1011/ 10newman.pdf

Newman, S. J., Wakefield, C. B., Williams, A. J., O'Malley, J. M., Nicol, S. J., DeMartini, E. E., et al. (2015). International workshop on methodological evolution to improve estimates of life history parameters and fisheries management of data-poor deep-water snappers and groupers. Mar. Pol. 60, 182-185. doi: 10.1016/j.marpol.2015.06.020

Newman, S. J., Wakefield, C. B., Williams, A. J., O’Malley, J. M., Taylor, B. M., Nicol, S. J., et al. (2017a). International workshop on advancing methods to overcome challenges associated with life history and stock assessments of data-poor deep-water snappers and groupers. Mar. Pol. 79, 78-83. doi: 10.1016/j.marpol.2017.02.009

Newman, S. J., Wakefield, C., Skepper, C., Boddington, D., Blay, N., Jones, R., et al. (2017b). "North coast demersal resource status report," in Status Reports of the Fisheries and Aquatic Resources of Western Australia 2015/16: State of the Fisheries eds W. F. Fletcher, M. D. Mumme, and F. J. Webster. Department of Fisheries, Western Australia), 144-152

Newman, S. J., Williams, A. J., Wakefield, C. B., Nicol, S. J., Taylor, B. M., and O'Malley, J. M. (2016). Review of the life history characteristics, ecology and fisheries for deep-water tropical demersal fish in the Indo-Pacific region. Rev. Fish Biol. Fish. 26, 537-562. doi: 10.1007/s11160-016-9442-1

Newman, S. J., Williams, D. Mc B., and Russ, G. R. (1996a). Variability in the population structure of Lutjanus adetii (Castelnau, 1873) and $L$. quinquelineatus (Bloch, 1790) among reefs in the central Great Barrier Reef, Australia. Fish. Bull. 94, 313-329.

Newman, S. J., Williams, D. M., and Russ, G. R. (1996b). Age validation, growth and mortality rates of the tropical snappers (Pisces: Lutjanidae) Lutjanus adetii (Castelnau, 1873) and L. quinquelineatus (Bloch, 1790) from the central Great Barrier Reef, Australia. Mar. Freshw. Res. 47, 575-584. doi: 10.1071/MF9960575

Norse, E. A., Brooke, S., Cheung, W. W. L., Clark, M. R., Ekeland, I., Froese, R., et al. (2012). Sustainability of deep-sea fisheries. Mar. Pol. 36, 307-320. doi: 10.1016/j.marpol.2011.06.008

O'Malley, J. (2015). A Review of the Cooperative Hawaiian Bottomfish Tagging Program of the Pacific Islands Fisheries Science Center and the Pacific Islands Fisheries Group. Pacific Islands Fish. Sci. Cent., Natl. Mar. Fish. Serv., NOAA, Honolulu, HI 96818-5007. Pacific Islands Fish. Sci. Cent. Admin. Rep. H-15-05.

Pitcher, C. R. (1992). Growth of juvenile coral reef damselfish: spatial and temporal variability, and the effect of population density. Aust. J. Mar. Freshw. Res. 43, 1129-1149. doi: 10.1071/M.F.9921129

R Core Team (2016). R: A Language and Environment for Statistical Computing. Vienna: R Foundation for Statistical Computing. Available online at: https:// www.R-project.org

Robertson, D. R., Ackerman, J. L., Choat, J. H., Posada, J. M., and Pitt, J. (2005). Ocean surgeonfish Acanthurus bahianus. I. The geography of demography. Mar. Ecol. Prog. Ser. 295, 229-244. doi: 10.3354/meps295229

Rochet, M. J., and Trenkel, V. M. (2003). Which community indicators can measure the impact of fishing? A review and proposals. Can. J. Fish. Aquat. Sci. 60, 86-99. doi: 10.1139/f02-164

Roemmich, D., and Gilson, J. (2009). The 2004-2008 mean and annual cycle of temperature, salinity, and steric height in the global ocean from the Argo Program. Prog. Oceanogr. 82, 81-100. doi: 10.1016/j.pocean.2009.03.004

Roff, D. A. (1983). An allocation model of growth and reproduction in fish. Can. J. Fish. Aquat. Sci. 40, 1395-1404. doi: 10.1139/f83-161

Sadovy, Y., and Shapiro, D. Y. (1987). Criteria for the diagnosis of hermaphroditism in fishes. Copeia 1987, 136-156. doi: 10.2307/1446046

Smith, M. K., and Kostlan, E. (1991). Estimates of age and growth of ehu Etelis carbunculus in four regions of the Pacific from density of daily increments in otoliths. Fish. Bull. 89, 461-472.
Trip, E. L., Choat, J. H., Wilson, D. T., and Robertson, D. R. (2008). Inter-oceanic analysis of demographic variation in a widely distributed Indo-Pacific coral reef fish. Mar. Ecol. Prog. Ser. 373, 97-109. doi: 10.3354/meps07755

Wakefield, C. B., Newman, S. J., and Boddington, D. K. (2013a). Exceptionally longevity, slow growth and late maturation infer high inherent vulnerability to exploitation for bass groper Polyprion americanus (Teleostei: Polyprionidae). Aquatic Biol. 18, 161-174. doi: 10.3354/ab00501

Wakefield, C. B., Newman, S. J., Marriott, R. J., Boddington, D. K., and Fairclough, D. V. (2013b). Contrasting life history characteristics of the eightbar grouper Hyporthodus octofasciatus (Pisces: Epinephelidae) over a large latitudinal range reveals spawning omission at higher latitudes. ICES J. Mar. Sci. 70, 485-497. doi: 10.1093 /icesjms/fst020

Wakefield, C. B., Newman, S. J., and Molony, B. W. (2010). Age-based demography and reproduction of hapuku, Polyprion oxygeneios, from the south coast of Western Australia: implications for management. ICES J. Mar. Sci. 67, 1164-1174. doi: 10.1093/icesjms/fsq021

Wakefield, C. B., O’Malley, J. M., Williams, A. J., Taylor, B. M., Nichols, R. S., Halafihi, T., et al. (2017a). Ageing bias and precision for deep-water snappers: evaluating nascent otolith preparation methods using novel multivariate comparisons among readers and growth parameter estimates. ICES J. Mar. Sci. 74, 193-203. doi: 10.1093/icesjms/fsw162

Wakefield, C. B., Potter, I. C., Hall, N. G., Lenanton, R. C. J., and Hesp, S. A. (2017b). Timing of growth zone formations in otoliths of the snapper, Chrysophrys auratus, in subtropical and temperate waters differ and growth follows a parabolic relationship with latitude. ICES J. Mar. Sci. 74, 180-192.

Wakefield, C. B., Williams, A. J., Newman, S. J., Bunel, M., Boddington, D. K., Vourey, E., et al. (2015). Variations in growth, longevity and natural mortality for the protogynous hermaphroditic eightbar grouper Hyporthodus octofasciatus between the Indian and Pacific Oceans. Fish. Res. 172, 26-33. doi: 10.1016/j.fishres.2015.06.021

Wakefield, C. B., Williams, A. J., Newman, S. J., Bunel, M., Dowling, C. E., Armstrong, C. A., et al. (2014). Rapid and reliable multivariate discrimination for two cryptic Eteline snappers using otolith morphometry. Fish. Res. 151, 100-106. doi: 10.1016/j.fishres.2013.10.011

West, G. (1990). Methods for assessing ovarian development in fishes: a review. Aust. J. Mar. Freshw. Res. 41, 199-222. doi: 10.1071/MF9900199

Williams, A. J., Davies, C. R., Mapstone, B. D., and Russ, G. R. (2003). Scales of spatial variation in demography of a large coral-reef fish-an exception to the typical model? Fish. Bull. 101, 673-683. Available online at: https://www.st. nmfs.noaa.gov/spo/FishBull/1013/16willia.pdf

Williams, A. J., Loeun, K., Nicol, S. J., Chavance, P., Ducrocq, M., Harley, S. J., et al. (2013). Population biology and vulnerability to fishing of deepwater Eteline snappers. J. Appl. Ichthyol. 29, 395-403. doi: 10.1111/jai. 12123

Williams, A. J., Newman, S. J., Wakefield, C. B., Bunel, M., Halafihi, T., Kaltavara, J., et al. (2015). Evaluating the performance of otolith morphometrics in deriving age compositions and mortality rates for assessment of datapoor tropical fisheries. ICES J. Mar. Sci. 72, 2098-2109. doi: 10.1093/icesjms/ fsv042

Wootton, R. J. (1985). “Energetics of reproduction," in Fish Energetics, eds P. Tytler and P. Calow (London: Croom Helm), 231-254.

Conflict of Interest Statement: The authors declare that the research was conducted in the absence of any commercial or financial relationships that could be construed as a potential conflict of interest.

Copyright (C) 2017 Williams, Wakefield, Newman, Vourey, Abascal, Halafihi, Kaltavara and Nicol. This is an open-access article distributed under the terms of the Creative Commons Attribution License (CC BY). The use, distribution or reproduction in other forums is permitted, provided the original author(s) or licensor are credited and that the original publication in this journal is cited, in accordance with accepted academic practice. No use, distribution or reproduction is permitted which does not comply with these terms. 